\title{
Gömülü Betonarme Boruların Analitik ve Sayısal Yöntemler ile Tasarımı
}

\author{
Onur DEMIRC $\dot{I}^{1}$ \\ Havvanur KILIÇ ${ }^{2}$ \\ Gökhan YAZICI ${ }^{3}$
}

ÖZ

Gömülü betonarme borular, kentsel altyapının kritik bileşenleridir. Tasarımlarında, boru özellikleri, boruyu çevreleyen dolgu zemin, yataklama koşulları ve etki eden dış yükler dikkate alınarak ampirik veya sayısal yöntemler kullanılır. Bu çalışmada, uygulamada yaygın olarak kabul gören ampirik ve sayısal analiz yöntemleri dikkate alınarak yapılan tasarım hesaplarındaki farklılıklar geri dolgu malzeme türü, dolgu yüksekliği ve boru çapı değişimi dikkate alınarak parametrik analizler ile incelenmiştir. Çalışma sonuçları, sayısal analizlerde zemin-boru etkileşiminin gerçekçi olarak dikkate alınması nedeniyle hesaplanan gerekli donatı alanlarının geleneksel tasarım yöntemlerinden elde edilen değerlere göre daha düşük olduğunu göstermektedir.

Anahtar Sözcükler: Gömülü betonarme boru tasarımı, dolaylı tasarım, doğrudan tasarım, zemin-yapı etkileşimi, sayısal analiz.

\begin{abstract}
Design of Buried Reinforced Concrete Pipes with Analytical and Numerical Methods

Buried reinforced concrete pipes are critical components of urban infrastructure. Their design can be conducted using empirical or numerical methods, which consider the properties of the pipes, backfill surrounding the pipe, bedding conditions and loads acting on the pipes. In this paper, a parametric study taking into account different backfill materials, burial depths, and pipe diameters was utilized to investigate the differences in design calculations obtained from widely accepted empirical and numerical analysis methods. Results indicate that required
\end{abstract}

\footnotetext{
Not: Bu yazı

- Yayın Kurulu’na 28 Kasım 2020 günü ulaşmıştır. 6 Ekim 2021 günü yayımlanmak üzere kabul edilmiştir.

- 31 Ocak 2023 gününe kadar tartışmaya açıktır.

- https://doi.org/10.18400/tekderg.832727

1 Yıldız Teknik Üniversitesi, İnşaat Mühendisliği Bölümü, İstanbul onurdemirci1094@gmail.com - https://orcid.org/0000-0002-3385-3056

2 Yıldız Teknik Üniversitesi, İnşaat Mühendisliği Bölümü, İstanbul kilic@yildiz.edu.tr - https://orcid.org/0000-0001-9455-1687

3 İstanbul Kültür Üniversitesi, İnşaat Mühendisliği Bölümü, İstanbul gokhanyazici@iku.edu.tr - https://orcid.org/0000-0002-6719-9152
} 
reinforcement areas calculated using numerical analyses are smaller than those obtained from traditional design methods due to realistic consideration of soil-pipe interaction.

Keywords: Buried concrete pipe design, indirect method, direct method, soil-structure interaction, numerical analysis.

\section{GİRIŞ}

Kent yaşamının sürdürülebilmesinde önemli rolü olan gömülü boru hatları, tasarım ve inşa aşamalarında mühendislik hizmeti almalıdır. Tasarımda boru cinsi, gömülme tipi, yerel zemin koşulları, geri dolgu malzemesi türü ve boru üzerine etkiyecek statik ve dinamik etkiler dikkate alınarak zemin-yapı etkileşimi problemi olarak incelenmelidir. Uygulamada, rijit betondan esnek plastik malzemelere kadar çok çeşitli boru cinsleri mevcuttur. Boru üretiminde genellikle rijit ve esnek boru olmak üzere 2 tip sınıflama yapılmıştır. Esnek boru, yenilme ve göçme belirtileri göstermeden \%2'den fazla şekil değiştirebilen borular, bu özelliklere sahip olmayan borular ise rijit boru olarak tanımlanmaktadır [1]. Rijit borular, üzerine aktarılan gerilmeleri kendi rijitliği ile karşılamakta, çevresindeki geri dolgu zeminden de beton boru üzerine yük aktarılmaktadır. Rijit borular donatılı, donatısız beton borular ve sırlı kil boruları içermektedir. Çekme donatısı ile birlikte rijit borular basınç borusu olarak iyi hizmet sunabilmektedir [2].

Dairesel kesitli betonarme boru (RCP) bir asır boyunca kullanılmakta ve birçok durumda güvenilir, uzun vadede dayanımlı su iletme yapısı olarak bilinmektedir. Boru en kesitinde düşey eksende merkezden geçen çizgiye merkez çizgisi, yatay eksende merkezden geçen çizgiye yatay simetri çizgisi denir. Borunun üst noktası taç, alt noktası taban ve yatay simetri çizgisinin kestiği noktalar ise yan duvar olarak adlandırılmaktadır. Boru duvarı et kalınlığı ise boru dış çapı ile iç çapı arasındaki farktır [3]. Gömülü boruya iletilen toprak yükü büyük oranda gömülme durumuna bağlıdır.

Bu çalışmada, gömülü betonarme boru tasarımında kullanılan yöntemler incelenerek boru çapı, dolgu yüksekliği, geri dolgu özelliği ve yatak malzemesi vb. değişimlerin boru tasarımına etkileri değerlendirilmiştir. Bu kapsamda tipik bir hendek durumunda gömülü betonarme boru problemi önce konvansiyonel yöntemler olarak adlandırılan dolaylı ve doğrudan tasarım yöntemleri ile daha sonra da zemin-yapı etkileşim problemlerinin çözümünde yaygın olarak kullanılan sonlu elemanlar yöntemi kullanılarak sayısal analizler ile incelenmiş ve elde edilen hesap sonuçlarının karşılaştırılması yapılmıştır. Dolaylı ve doğrudan tasarım yöntemlerinin sayısal analizlere göre gerekli donatı alanlarında daha konservatif sonuçlar verdiği belirlenmiştir. Dolaylı tasarım yönteminde boru gömülme derinliği ile geri dolgu malzemesinin birim hacim ağırlığı arttığında 0.01 inç $(0.254 \mathrm{~mm})$ 'lik çatlama kriterine denk gelen tasarım yüklerinin arttığı ve daha yüksek bir boru sınıfı ve donatı alanı gerektiği tespit edilmiştir. Özellikle, 1 m'den daha küçük iç çaplı boru kullanıldığında, $12 \mathrm{~m}$ gibi yüksek dolgular altında elde edilen çatlama kriterine denk gelen tasarım D-Yükleri ASTM C76 Şartnamesinde belirtilen doruk D-Yüklerini $(175 \mathrm{kN} / \mathrm{m} / \mathrm{m})$ aştığ 1 belirlenmiştir. Böylelikle, $12 \mathrm{~m}$ gibi yüksek dolgu yüklerine maruz kalacak uygulamalarda, boru iç çapı 1m'den küçük borular için dolaylı tasarım yönteminin kullanılması önerilmemektedir. Doğrudan tasarım yönteminin ise Heger basınç dağılımlarında kullanılmakta olan ve kurulum tiplerine göre kısmen değişen düşey kemerlenme faktörlerinin (VAF) borunun gömülme yüksekliği artırıldığında zemin kemerlenme etkisini yansıtamadığı için konservatif 
sonuçlar verdiği tespit edilmiştir. Doğrudan tasarım yöntemi, boru tasarımında kullandığ1 standart kurulum tipleri, boyutsuz katsayılar ve limit durum yaklaşımıyla boru-zemin etkileşimini dikkate alırken, ampirik dolaylı tasarım yöntemine göre önemli ölçüde gelişmeler sunmuş fakat sofistike sonlu elemanlar yöntemi çözümü kadar gerçekçi olamadığı düşünülmektedir.

\section{BETONARME BORU TASARIM YÖNTEMLERI}

Günümüzde gömülü betonarme boruların tasarımında, dolaylı tasarım ve doğrudan tasarım yöntemi olmak üzere iki ana tasarım yöntemi mevcuttur. Tarihsel sürece bakıldığında, 1900'lü yıllardan itibaren boruların tasarımı için arazide gerçek boyutlu deneysel çalışmalar, laboratuvarda model deneyler ve iki boyutlu ve üç boyutlu sayısal analizler yapılmış ve halen günümüzde de çalışmalar sürdürülmektedir. Marston (1930)'da zemin mekaniği temel ilkelerini dikkate alarak gömülü borular üzerine etkiyen zemin yüklerinin hesaplanması için bir yöntem geliştirmiştir [4]. Bu yaklaşımda, boru üzerine etkiyen düşey yüklerin, borunun üstündeki zemin prizması ve ilave hareketli yükten oluştuğu kabul edilmiş ve hendek yan duvarları ve geri dolgu malzemesi arasındaki sürtünme nedeniyle düşey basıncın bir miktar azaldığı dikkate alınmıştır. Spangler (1933) ise çalışmalarında standart laboratuvar deneyi olarak rijit borunun dayanımını ölçen üç-kenarlı deneyi (TEB) kullanmıştır. Spangler'in araştırmasının amacı, bu üç-kenarlı deney (TEB) ile elde edilen boru dayanımını arazi koşullarındaki boru dayanımına oranlamaktır. Spangler (1933)'de, bu oranı bir yük faktörü gibi dikkate alınmış ve sonraki çalışmalarda bu yük faktörü geliştirilerek yataklama katsayısı olarak kullanılmıştır [5].

\subsection{Dolaylı Tasarım Yöntemi}

Marston ve Spangler'in çalışmaları, hala günümüzde kullanılmakta olan dolaylı tasarım yönteminin temellerini oluşturmuştur. Dolaylı tasarım yöntemi, boruya etkiyen toplam zemin ve yüzey yüklerinin ampirik yöntemler ile hesaplanmasına dayanmaktadır. Bu yöntem, üçkenarlı deneyde oluşan 0.01 inç $(0.254 \mathrm{~mm})$ 'lik çatlama kriteri ile beton boru dayanımının elde edilmesi esasına dayanmaktadır. Bu deneyin şematik gösterimi Şekil 1'de gösterilmiştir.
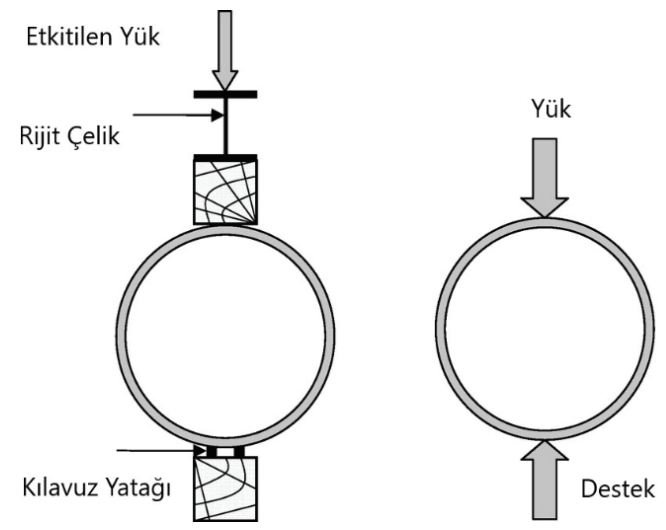

Şekil 1 - Üç Kenarlı Deney (TEB) ve boru yükleme durumu [6] 
Yönteme göre, hendekte boru taç bölgesi üzerine etkiyen gerilmeler boru tarafından taşınmaktadır. Borunun mukavemeti, eşdeğer üç-kenarlı deney yükü olarak da bilinen toplam yükün yataklama katsayısına oranı ile elde edilen yük ile belirlenir. Zemin yükü, eşdeğer üçkenarlı deney (TEB) yüküne bir yataklama faktörü $B_{f}$ ve güvenlik katsayısı F.S ile dönüştürülmektedir.

Üç-kenarlı deney yükü betonarme boru tasarımı için temsili bir değerdir ve deneyde borunun göstereceği performans kalite kontrol kriteri olarak değerlendirilir. Bu yöntemde, tasarım yükü (D-Yükü) Denklem 1 ile hesaplanır. Bu eşitlikte, W toplam yük, $\mathrm{B}_{\mathrm{f}}$ yataklama katsayısı, F.S güvenlik katsayısı (1.25 ve 1.5 arasında alınabilir) ve $\mathrm{D}_{\mathrm{i}}$ boru iç çapıdır.

$D y \ddot{u} k \ddot{u}=\frac{W}{B f} \frac{F \cdot S}{D i}$

Yataklama katsayısı, gömülü borunun destekleyici mukavemetinin üç-kenarlı deneyden hesaplanan boru mukavemetine oranıdır. Dolaylı tasarım yönteminde Marston (1930)'un geliştirdiği 4 adet geleneksel kurulum sınıfları kullanılır. Bu kurulum sınıfları, yataklama kalitesine göre en elverişsiz durum olan D sınıfından en kaliteli yataklama sınıfı A'ya doğru sıralanmaktadır. Dolaylı tasarım yönteminde Denklem 1'de görüldüğü üzere gerekli destekleyici dayanım yükü; yataklama faktörü, toplam yük ve güvenlik sayısının bir fonksiyonudur. Elde edilen bu yük üç-kenarlı deney (TEB) yüküdür. Bu yük, D-yükü olarak da bilinen tasarım mukavemeti yükü, boru iç çapına (Di) bölünerek dönüştürülmektedir. D-yüküne göre ASTM C76 Şartnamesinden ilgili boru sınıfları, beton dayanımları, boru duvar kalınlıkları ve donatılandırma gereksinimleri seçilmektedir. Yaygın sınıflamalar arasında 50D, 65D, 100D ve 140D yer almaktadır. Elde edilen boru sınıflarına ve D-Yüküne göre boru et kalınlıkları, boru çapları, gerekli donatı alanları gibi tasarım parametreleri elde edilir. Boru sınıflarına karşılık gelen 0.01 inç $(0.254 \mathrm{~mm})$ çatlama D-Yükleri ve doruk çatlama D-Yükleri Tablo 1'de verilmiştir.

Tablo 1 - Boru Sinıflarına Göre D-Yükleri [7]

\begin{tabular}{|c|c|c|}
\hline Boru Sinıfları & $\begin{array}{l}\text { 0.01 İnç Çatlama D- } \\
\text { Yükleri }(\mathrm{kN} / \mathrm{m} / \mathrm{m})\end{array}$ & $\begin{array}{l}\text { Doruk Çatlama D-Yükleri } \\
(\mathrm{kN} / \mathrm{m} / \mathrm{m})\end{array}$ \\
\hline I & 40 & 60 \\
\hline II & 50 & 75 \\
\hline III & 65 & 100 \\
\hline IV & 100 & 150 \\
\hline $\mathrm{V}$ & 140 & 175 \\
\hline
\end{tabular}

\subsection{Doğrudan Tasarım Yöntemi}

Amerikan Beton Boru Derneği (ACPA) 1970'li yıllarda, Marston ve Spangler'in geliştirdiği kurulum tiplerine yeni bir bakış kazandırma ve modernleştirme amacı ile zemin-boru etkileşimini de işin içine katarak yeni bir tasarım yöntemi çalışması yürütmüştür. Bu çalışmalar kapsamında, gömülü boru ile onu çevreleyen zeminin etkileşimi incelenmiş ve 
Heger (1988), bu araştırmalar sonucunda SPIDA (Zemin-Boru Etkileşimi Tasarımı ve Analizi) adlı sonlu elemanlar yazılımını geliştirmiştir. Paris (1921) ve Olander (1950) tarafından geliştirilen basınç dağılımları geçmişte kullanılmış olup, bugün geniş kitlelerce daha yaygın olarak Heger (1988) basınç dağılımı kullanılmaktadır. ACPA önderliğinde geliştirilen SPIDA yazılımı, Heger basınç dağılımının ortaya çıkması ve toprak yüklerinin hesabında önemli rol oynayarak Doğrudan tasarım yönteminin başlangıcı olarak belirtilmiştir [8]. ACPA'nın araştırma programı sayesinde, Marston ve Spangler'in geleneksel A, B, C ve D kurulum tipleri, yerini Heger' in geliştirdiği SPIDA yazılımı ile 4 adet yeni ve modern Tip 1, Tip 2, Tip 3 ve Tip 4 kurulum tiplerine bırakmıştır. Bu kurulum tipleri ve Heger basınç dağılımları, Amerikan İnşaat Mühendisleri Derneği (ASCE) tarafından incelenmiş ve "Gömülü Öndökümlü Beton Boruların Doğrudan Tasarımı İçin Standart Kurulumlar (SIDD)" olarak ASCE 15-98 Şartnamesi halinde birleştirilmiştir. Birleştirilmiş Zemin Sınıflandırma Sistemi (USCS) ve Amerikan Karayolları Birliği (AASHTO)'nin doğrudan tasarım için uygun gördüğü zemin tipleri ve sınıfları Tablo 2'de gösterilmiştir. Bu sınıflandırmalara göre I ve II numaralı kategoriler iri daneli zeminleri, III numaralı kategori ise ince daneli zeminleri ifade etmektedir. IV numaralı kategori $\mathrm{CH}$ (yüksek plastisiteli kil) zemin kullanıldığında, boru kurulumunda yatak malzemesi kullanılmaması gerektiği belirtilmiştir.

Tablo 2 - SIDD (Doğrudan Tasarım) Zemin Belirlemesi için Eşdeğer USCS ve AASHTO Zemin Sinıflandırmaları [10]

\begin{tabular}{|c|c|c|c|c|}
\hline $\begin{array}{c}\text { SIDD } \\
\text { Zemini }\end{array}$ & $\begin{array}{c}\text { USCS } \\
\text { Zemin Sinıflandırma } \\
\text { Sistemi }\end{array}$ & $\begin{array}{c}\text { AASHTO } \\
\text { Zemin } \\
\text { Sinıflandırma } \\
\text { Sistemi }\end{array}$ & $\begin{array}{c}\text { Sikıştırma } \\
\text { Derecesi } \\
(\%)\end{array}$ & $\begin{array}{c}\text { Modifiye } \\
\text { Sikıştırma } \\
\text { Derecesi } \\
(\%)\end{array}$ \\
\hline $\begin{array}{c}\text { Çakıllı Kum } \\
\text { (Tip I) }\end{array}$ & SW, SP, GW, GP. & A1, A3 & $\begin{array}{c}100,95,90, \\
85,80,61\end{array}$ & $\begin{array}{c}95,90,85, \\
80,75,59\end{array}$ \\
\hline $\begin{array}{c}\text { Kumlu Silt } \\
\text { (Tip II) }\end{array}$ & $\begin{array}{c}\text { GM, SM, ML ve \#200 } \\
\text { No'lu elekten } \\
\text { geçenler \%20'den az } \\
\text { olmak koşuluyla GC, SC. }\end{array}$ & A2, A4 & $\begin{array}{c}100,95,90, \\
85,80,49\end{array}$ & $\begin{array}{c}95,90,85, \\
80,75,46\end{array}$ \\
\hline $\begin{array}{c}\text { Siltli Kil } \\
\text { (Tip III) }\end{array}$ & CL, MH, GC, SC. & A5, A6 & $\begin{array}{c}100,95,90, \\
85,80,45\end{array}$ & $\begin{array}{c}90,85,80, \\
75,70,40\end{array}$ \\
\hline $\begin{array}{c}\text { Yüksek } \\
\text { Plastisiteli } \\
\text { Kil (Tip IV) }\end{array}$ & \multicolumn{2}{|c|}{ A7 } & $\begin{array}{c}100,95,90, \\
45\end{array}$ & $90,85,80$, \\
\end{tabular}

Doğrudan tasarım yönteminde, standart kurulum tipini belirlemek için boru kurulum inşa kalitesi çok önemlidir. Tip 1 en yüksek boru kurulum kalitesini gerektirmekte, Tip 2 ve Tip 3'e doğru boru kurulum kalitesi giderek azalmaktadır. Tip 4 ise neredeyse hiçbir kurulum kalite koşulu gerektirmezken buna karşılık olarak yüksek boru mukavemeti gerektirmektedir. Tablo 3'te doğrudan tasarım için standart kurulum tipleri ve en düşük kompaksiyon 
gereksinimleri belirtilmiştir. Burada $\mathrm{D}_{0}$ boru dış çapını ifade etmektedir. Doğrudan tasarım yönteminde yukarıda bahsedildiği üzere Tablo 2'de verilmiş zemin kategorileri ve Tablo 3 'te verilmiş olan standart kurulum tipleri için Heger toprak basıncı dağılımları kullanılmaktadır. Heger toprak basıncı dağılımları, her standart kurulum tipi için belirli bir terminolojide zemin içerisine gömülmüş boruya etkiyen yüklerin ve gerilme dağılımlarının hesaplanmasında kullanılmaktadır (Şekil 2). Burada A1-A6 katsayıları toprak basıncının boyutsuz düşey ve yatay bileşenleri, a-v ise boyutsuz düşey ve yatay ölçüleri tanımlamak için kullanılan katsayılar olup, kurulum tipine göre hesaplanan düşey kemerlenme faktörü (VAF) ve yatay kemerlenme faktörü (HAF) doğrudan tasarım yönteminde toprak yüklerinin ve gerilmelerinin hesaplanmasında kullanılmaktadır [9]. Diğer katsayılar d, h1 ve h2 aşağıda belirtildiği gibi Denklem 2, 3 ve 4 ile hesaplanabilir. Doğrudan tasarım yöntemindeki Standart 4 adet kurulum tiplerine göre Heger zemin basınc1 ve kemerlenme faktörü katsayıları Tablo 4'te verilmiştir.

Tablo 3 - SIDD (Doğrudan Tasarım) için Standart Kurulum Tipleri ve En Düşük Kompaksiyon Gereksinimleri [10]

\begin{tabular}{|c|c|c|c|}
\hline $\begin{array}{l}\text { Kurulum } \\
\text { Tipi }\end{array}$ & Yatak Kalınlığı & $\begin{array}{c}\text { Boru Alt Yan } \\
\text { Kismindaki } \\
\text { Malzeme }\end{array}$ & $\begin{array}{l}\text { Hendek Duvarı } \\
\text { Alt Kısmındaki } \\
\text { Malzeme }\end{array}$ \\
\hline Tip 1 & $\begin{array}{l}75 \text { mm'den küçük olmamak } \\
\text { kaydıyla Do/24. } \\
\text { Tabanda kaya bulunuyorsa } 150 \\
\text { mm'den küçük olmamak } \\
\text { kaydıyla Do/12. }\end{array}$ & $\begin{array}{c}\% 95 \\
\text { Kategori I }\end{array}$ & $\begin{array}{c}\% 90 \text { Kategori I } \\
\% 95 \text { Kategori II } \\
\% 100 \text { Kategori III }\end{array}$ \\
\hline Tip 2 & $\begin{array}{c}75 \text { mm’den küçük olmamak } \\
\text { kaydıyla } \mathrm{D}_{\mathrm{o}} / 24 . \\
\text { Tabanda kaya bulunuyorsa } 150 \\
\text { mm'den küçük olmamak } \\
\text { kaydiyla } \mathrm{D}_{0} / 12 .\end{array}$ & $\begin{array}{c}\% 90 \text { Kategori I } \\
\text { veya } \% 95 \\
\text { Kategori II }\end{array}$ & $\begin{array}{c}\text { \%85 Kategori I } \\
\% 90 \text { Kategori II } \\
\% 95 \text { Kategori III }\end{array}$ \\
\hline Tip 3 & $\begin{array}{c}75 \text { mm’den küçük olmamak } \\
\text { kaydıyla Do/24. } \\
\text { Tabanda kaya bulunuyorsa } 150 \\
\text { mm'den küçük olmamak } \\
\text { kaydıyla Do/12. }\end{array}$ & $\begin{array}{c}\% 85 \text { Kategori I } \\
\% 90 \text { Kategori II } \\
\% 95 \text { Kategori III }\end{array}$ & $\begin{array}{c}\text { \%85 Kategori I } \\
\% 90 \text { Kategori II } \\
\% 95 \text { Kategori III }\end{array}$ \\
\hline Tip 4 & $\begin{array}{c}\text { Yatak gerekmez (taban } \\
\text { bölgesinde kaya yoksa). } \\
\text { Eğer taban bölgesinde kaya } \\
\text { bulunuyorsa } 150 \text { mm'den küçük } \\
\text { olmamak kaydıyla } \mathrm{D}_{0} / 12 \text {. }\end{array}$ & $\begin{array}{c}\text { Kompaksiyon } \\
\text { gerekmez. } \\
\text { (Kategori III } \\
\text { kullanılması } \\
\text { dişında) } \\
\text { \%85 Kategori III }\end{array}$ & $\begin{array}{c}\text { Kompaksiyon } \\
\text { gerekmez. } \\
\text { (Kategori III } \\
\text { kullanılması } \\
\text { dişında) } \\
\text { \%85 Kategori III }\end{array}$ \\
\hline
\end{tabular}




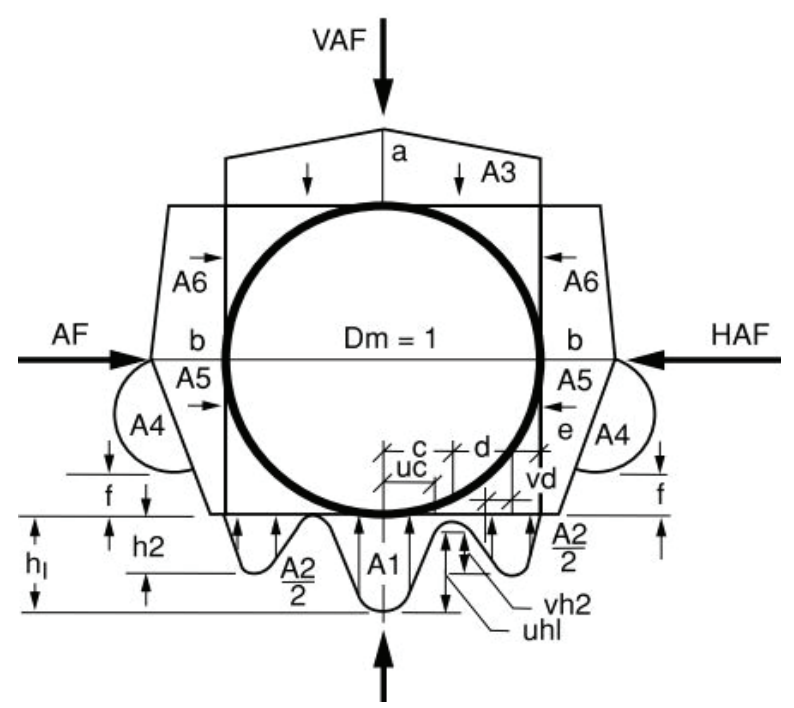

Şekil 2 - Heger Zemin Basıncı Dă̆glımları [10]

Tablo 4 - Standart Kurulum Tiplerine Göre Heger Zemin Basıncı ve Kemerlenme Faktörü Katsayılarl [10]

\begin{tabular}{|c|c|c|c|c|}
\hline \multirow{2}{*}{ Katsayılar } & \multicolumn{4}{|c|}{ Kurulum Tipleri } \\
\cline { 2 - 5 } & Tip 1 & Tip 2 & Tip 3 & Tip 4 \\
\hline VAF & 1.35 & 1.40 & 1.40 & 1.45 \\
\hline HAF & 0.45 & 0.40 & 0.37 & 0.30 \\
\hline A1 & 0.62 & 0.85 & 1.05 & 1.45 \\
\hline A2 & 0.73 & 0.55 & 0.35 & 0.00 \\
\hline A3 & 1.35 & 1.40 & 1.40 & 1.45 \\
\hline A4 & 0.19 & 0.15 & 0.10 & 0.00 \\
\hline A5 & 0.08 & 0.08 & 0.10 & 0.11 \\
\hline A6 & 0.18 & 0.17 & 0.17 & 0.19 \\
\hline a & 1.40 & 1.45 & 1.45 & 1.45 \\
\hline b & 0.40 & 0.40 & 0.36 & 0.30 \\
\hline c & 0.18 & 0.19 & 0.20 & 0.25 \\
\hline e & 0.08 & 0.10 & 0.12 & 0.00 \\
\hline f & 0.05 & 0.05 & 0.05 & - \\
\hline u & 0.80 & 0.82 & 0.85 & 0.90 \\
\hline v & 0.80 & 0.70 & 0.60 & - \\
\hline
\end{tabular}




$$
\begin{aligned}
& d=0.5-c-e \\
& h 1=\frac{(1.5 A 1)}{c(1+u)} \\
& h 2=\frac{(1.5 \mathrm{~A} 2)}{[\mathrm{d}(1+\mathrm{u})+2 \mathrm{e}]}
\end{aligned}
$$

Boru üzerine etkiyen toplam düşey ve yatay yükler, SPIDA yazılımıyla zemin-yapı etkileşimi dikkate alınarak elde edilen kemerlenme katsayılarının boru üzerindeki prizma yükü (PL) ile çarpılmasıyla bulunur. Prizma yükü, Denklem 5'teki gibi hesaplanmaktadır.

$$
P L=\frac{w D_{0}}{100}\left(H+\frac{0.107 D_{0}}{1000}\right)
$$

Burada; PL Prizma yükü, w zemin birim hacim ağırlığı $\left(\mathrm{kN} / \mathrm{m}^{3}\right), \mathrm{D}_{0}$ borunun dış çapı $(\mathrm{m}), \mathrm{H}$ ise borunun üst kısmındaki dolgu yüksekliği (m)'dir. Boru üzerindeki toplam düşey zemin yükü, prizma yükü ile düşey kemerlenme faktörü (VAF)'nün çarpımıyla elde edilir. Toplam düşey zemin yükü, Denklem 6 ile hesaplanmaktadır.

$W=P L \times H A F$

Toplam düşey zemin yükü bulunduktan sonra ASCE 15-98' de belirtilen her standart kurulum tiplerine göre (I-IV) belirlenmiş olan boru taban bölgesi, yatay simetri çizgisi bölgesi, taban ve taç bölgeleri içerisindeki kritik kesme bölgeleri ve taç bölgeleri için moment, eksenel kuvvet ve kesme kuvvetleri hesabı doğrultusunda belirlenmiş boyutsuz katsayılar ile Denklem 7, 8 ve 9 ile tesir kuvvetleri hesaplanıp donatılar belirlenmektedir (ASCE 15-98 Tablo C-3.1, 3.2, 3.3, 3.4).

$$
\begin{aligned}
& M_{i}=\Sigma \frac{C m_{i} W_{i} D_{m}}{2} \\
& N_{i}=\Sigma c_{n_{i}} w_{i} \\
& V_{i}=\Sigma C v_{i} w_{i}
\end{aligned}
$$

Burada; $\mathrm{C}_{\mathrm{mi}}$ Moment hesabı için boru analiz katsayısını, $\mathrm{C}_{\mathrm{ni}}$ Eksenel kuvvet hesabı için boru analiz katsayısını, $\mathrm{C}_{\mathrm{vi}}$ Kesme kuvveti hesabı için boru analiz katsayısını, $\mathrm{W}_{\mathrm{i}}$ Boru üzerine gelecek yüklerin toplamını, $\mathrm{D}_{\mathrm{m}}$ ise boru ortalama çapını temsil etmektedir. Doğrudan tasarım yönteminde, gömülü beton boruların donatı hesabında ASCE 15-98 Şartnamesi'nde belirtilen Denklem 10 kullanılmaktadır. Bu denklemde; As birim uzunluk için gerekli eğilme donatısı alanı, $\mathrm{g}=0.85 \mathrm{bf}_{\mathrm{c}}$, $\mathrm{b}$ hesapta kullanılan genişliği $(\mathrm{m})$, h boru duvar kalınlığını ve $\mathrm{d}$ ise pas payını göstermektedir. Beton malzemesinin dayanımı ve donatı akma dayanımı $f_{c}$ ve $f_{y}$ ile ifade edilmektedir. Eğilme donatısı için direnç faktörü $\Phi=0.9$ alınmakta ve $M_{u}, N_{u}$ sırası ile b genişliğine etkiyen tasarım momenti ve tasarım eksenel kuvvetini ifade etmektedir.

$$
A_{S}=\frac{g \Phi f_{\mathrm{d}}-\mathrm{N}_{\mathrm{u}}-\sqrt{\mathrm{g}\left[\mathrm{g}\left(\Phi \mathrm{f}_{\mathrm{d}}\right)^{2}-\mathrm{N}_{\mathrm{u}}\left(2 \Phi \mathrm{f}_{\mathrm{d}}-\mathrm{h}\right)-2 \mathrm{M}_{\mathrm{u}}\right]}}{\mathrm{f}_{\mathrm{y}}}
$$


Doğrudan tasarım yöntemi kapsamında, zemin parametrelerine ve standart kurulum tiplerine bağlı olarak Heger basınç dağılımları kullanılarak gömülü boruya etkiyen zemin yükleri ve basınç dağılımları belirlenerek, kesit tesirleri ve gerekli boru donatısı hesaplanmaktadır.

$\mathrm{Bu}$ araştırma makalesinin amacı, konvansiyonel yöntemlerin (dolaylı ve doğrudan tasarım) gömülü betonarme boru tasarımında kullanımının yeterliliğini sonlu elemanlar analizleri ile karşılaştırarak sorgulamaktır. Böylece konvansiyonel yöntemlerin sayısal yöntemlerle karşılaştırılması sonucu, tasarımda ne ölçüde konservatif davrandığı ve boru-zemin etkileşimini irdelemekte ne kadar başarı sağladığı incelenmiştir. Kurdziel ve McGrath (1991), yaptıkları çalışmada dolaylı ve doğrudan tasarım arasındaki farklılıkları gömülü betonarme boru tasarımında yapısal performans ve maliyet açısından değerlendirmişlerdir. Çalışmada, toplam donatı ihtiyacında dolaylı tasarım yönteminin doğrudan tasarım yöntemine göre konservatif davrandığ

Zhao ve Daigle (2001), yaptıkları çalışmada SIDD (Doğrudan tasarım) boru kurulumunu ve Ontario eyaletine ait standartları (OPSS) teknik gelişim, inşaat özellikleri ve maliyetleri açısından karşılaştırmış ve birbirlerine alternatif olarak düşünülebileceklerini ortaya koymuştur. Rijit (betonarme) borularda OPSS, geleneksel dolaylı tasarım (MarstonSpangler) yöntemi baz alınarak ortaya çıkmıştır. Güvenlik katsayıları kıyaslanacak olursa, SIDD yönteminde limit durum tasarımı yaklaşımı dikkate alınırken OPSS yönteminde tekil güvenlik katsayısı yaklaşımı kullanılmıştır. Bu bağlamda, SIDD yöntemi daha tutarlı bir güvenlik yaklaşımı sunmaktadır. Çalışma sonuçlarına bakıldığında geleneksel MarstonSpangler teorilerini baz alan yöntemin hala geçerli olduğunu fakat daha rasyonel bir yaklaşım için SIDD (Doğrudan Tasarım) yönteminin bir alternatif olarak düşünülmesi gerektiğini belirtmişlerdir [12].

Erdoğmuş ve Tadros (2006), gömülü betonarme boruların davranışı ve tasarımı üzerinde çalışmalar yaparak kısa ve uzun vadeli amaçlar belirtmişlerdir. Çalışmalarının kısa vadeli amaçlarına göre tasarım yöntemlerini karşılaştırarak, betonarme borular için bir tasarım kriteri ve rehberi oluşturmuşlardır. Çalışmalarının uzun vadeli amaçlarını ise beton boruların yapısal davranışını teorik olarak etkin bir şekilde çözümlemek, tasarım kriterlerini geliştirmek ve daha rasyonel, ekonomik ve güvenli tasarım yöntemleri elde etmek olarak belirtmişlerdir. Dolaylı ve doğrudan tasarım yöntemlerini karşılaştırarak Şekil 3 'te görüldüğü gibi SIDD Tip III kurulumunda 48inç (1200mm) çaplı boruda dolaylı ve doğrudan tasarım yöntemlerine göre hesaplanan donatı alanları sunulmuştur [13]. Şekil 3 'te dolgu yüksekliğine $(1 \mathrm{ft}=0.304 \mathrm{~m})$ ve beton malzeme dayanımı $(4000 \mathrm{psi}=27.57 \mathrm{MPa}, 5000 \mathrm{psi}=34.47 \mathrm{MPa})$ artışına bağlı olarak doğrudan tasarım yöntemine göre belirlenen donatı alanı sürekli bir artış göstermiş, dolaylı tasarım yönteminde ise kademeli bir artış olmuştur.

Erdoğmus ve Tadros (2009)'da üç-kenarlı deneylerin boruların gömüldüğü zemin içerisindeki davranışı doğru yansıtmadığını belirterek, boru tasarımında doğrudan tasarım yönteminin kullanılması gerektiğini ve üç-kenarlı deneyin (TEB) ve 0.01 inç $(0.254 \mathrm{~mm})$ 'lik çatlama kontrol limitinin hiçbir teknik kökene sahip olmadığını bu nedenle limit kontrolü olarak kullanılmaması gerektiği belirtilmiştir. Doğrudan tasarım yönteminin dolaylı tasarım yöntemine göre malzeme davranışlarını ve limit durumlarını ayarlamada daha gelişime açık olduğu vurgulanmıştır. Ayrıca, 36inç (914mm)'ten daha küçük çaplı borularda doğrudan tasarım yönteminin dolaylı tasarım yöntemine göre daha muhafazakar sonuçlar verdiği ve mutlaka yeniden gözden geçirilerek tasarımların yapılması gerektiği belirtilmiştir [14]. 


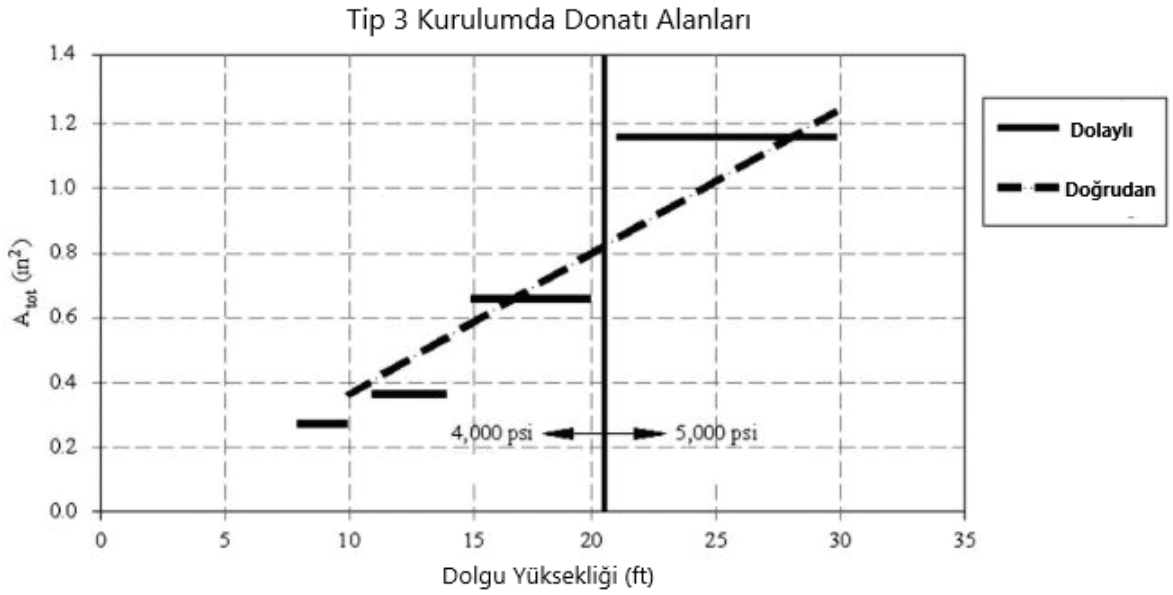

Şekil 3 - Tip III Kurulumda Dolgu Yüksekliği ve Donatı Alanı Karşılaştırması [13]

Allard ve Naggar (2016), yaptıkları çalışmada doğrudan tasarım (SIDD) yönteminde kullanılan Heger basınç dağılımlarının zemin-yapı etkileşimi kapsamında doğruluğu ve uygulanabilirliğini parametrik sayısal analizler (Plaxis 2D) ile araştırmışlardır. Çalışmada elde edilen en yüksek eğilme momenti değerlerinin borunun taban bölgesinde, en yüksek normal kuvvet değerlerinin ise yan duvar bölgesinde olduğu belirtilmiştir. Ayrıca gömülme derinliği arttıkça pozitif zemin kemerlenmesinin arttı̆̆ı, Heger basınç dağılımlarında kullanılmakta olan düşey kemerlenme faktörünün sabit tutulmasının konservatif sonuçlar doğurduğu ve genel olarak Heger yönteminin sonlu elemanlar yöntemine göre konservatif sonuçlar verdiği belirlenmiştir [15].

Beakley ve DelloRusso (2020) dolaylı ve doğrudan tasarım yöntemlerinin karşılaştırılması sonucunda, tasarımda gerekli donatı alanı ihtiyacında farklılıklar olduğunu ve her iki yöntemin de yeterince konservatif sonuçlar verdiğini belirtmişlerdir. Dolaylı tasarım yönteminin daha basit bir kurulum yöntemi olduğundan ve yaklaşık 70 yıllık kanıtlı performansa dayandığından kullanımının hala yaygın olduğu, ancak doğrudan tasarım yönteminin kullanımının daha efektif ve ekonomik olabileceğini vurgulamışlardır. Özellikle 48inç $(1200 \mathrm{~mm})$ ve üzeri boru çaplarında dolaylı tasarım yönteminin tasarımda etkisini yitirmeye başladığını belirtmişlerdir [16].

\section{VAKA ANALİí}

Bu çalışma kapsamında incelenen problemde, borunun gömülme yükseklikleri H1-H2-H3 (m) olarak sırasıyla $3 \mathrm{~m}, 6 \mathrm{~m}$ ve $12 \mathrm{~m}$ dikkate alınmıştır. Boru dış çapı değişimi Ø800-Ø1800 $\mathrm{mm}$ aralığındadır. Analizlerde kullanılan beton boru malzeme parametreleri Tablo 5'te, zemin parametreleri ise Tablo 6'da sunulmuştur. Yerel zemin, yatak ve geri dolgu malzemeleri için Pekleşen Zemin Modeli (HS Model) ve Kireçtaşı tabakası için ise MohrCoulomb (MC) bünye modeli kullanılmıştır. Doğrudan tasarım ve dolaylı tasarım yöntemleri kullanılarak yapılan analitik analizlerde zemin birim hacim ağırlıkları G1-G2-G3 olarak 
belirtilmiş olup sırasıyla 18, 20 ve $23 \mathrm{kN} / \mathrm{m}^{3}$ olarak dikkate alınmıştır. Değişen parametrelere göre boru tasarımı için gerekli olan donatı alanları hesaplanarak sonuçlar karşılaştırılmıştır. Problemin model geometrisi Şekil 4'te gösterilmiştir. Burada $\mathrm{D}_{\mathrm{o}}$ boru dış çapını ve $\mathrm{B}_{\mathrm{c}}$ hendek genişliğini ifade etmektedir. Analitik çalışmada konvansiyonel tasarım yöntemleri irdelendiği için yerel zemin ve yatak malzemesinin rijitlik parametreleri analizlerde kullanılmamıştır, dolayısıyla analitik çalışmada yalnızca geri dolgu malzemesinin rijitliği ve dolgu yüksekliklerinin etkileri dikkate alınabilmiştir.

Tablo 5 - Analitik ve sayısal analizlerde kullanılan beton boru özellikleri

\begin{tabular}{cccc}
\hline Parametreler & Birim & Analitik Analiz & Sayısal Analiz \\
\hline Boru İç Çapı (Di) & $\mathrm{mm}$ & 1500 & 1500 \\
\hline Duvar Kalınlığı $(\mathrm{h})$ & $\mathrm{mm}$ & $120-200$ & $120-200$ \\
\hline Elastisite Modülü $\left(\mathrm{E}_{\mathrm{c}}\right)$ & $\mathrm{GPa}$ & 30 & 30 \\
\hline Eksenel Rijitliği $(\mathrm{EA})$ & $\mathrm{kN} / \mathrm{m}$ & - & $6.4 \times 10^{6}$ \\
\hline Eğilme Rijitliği $(\mathrm{EI})$ & $\mathrm{kNm}{ }^{2} / \mathrm{m}$ & - & $21.33 \times 10^{3}$ \\
\hline Basınç Dayanımı $\left(\mathrm{f}_{\mathrm{c}}{ }_{\mathrm{c}}\right)$ & $\mathrm{MPa}$ & 45 & 45 \\
\hline Donatı Akma Dayanımı $\left(\mathrm{f}_{\mathrm{y}}\right)$ & $\mathrm{MPa}$ & 485 & 485 \\
\hline Yoğunluğu $\left(\gamma_{\mathrm{c}}\right)$ & $\mathrm{kN} / \mathrm{m}^{3}$ & 24 & 24 \\
\hline Poisson Oranı $(\mathrm{v})$ & - & 0.15 & 0.15 \\
\hline Ăğırlık $(\mathrm{w})$ & $\mathrm{kN} / \mathrm{m} / \mathrm{m}$ & - & 2.80
\end{tabular}

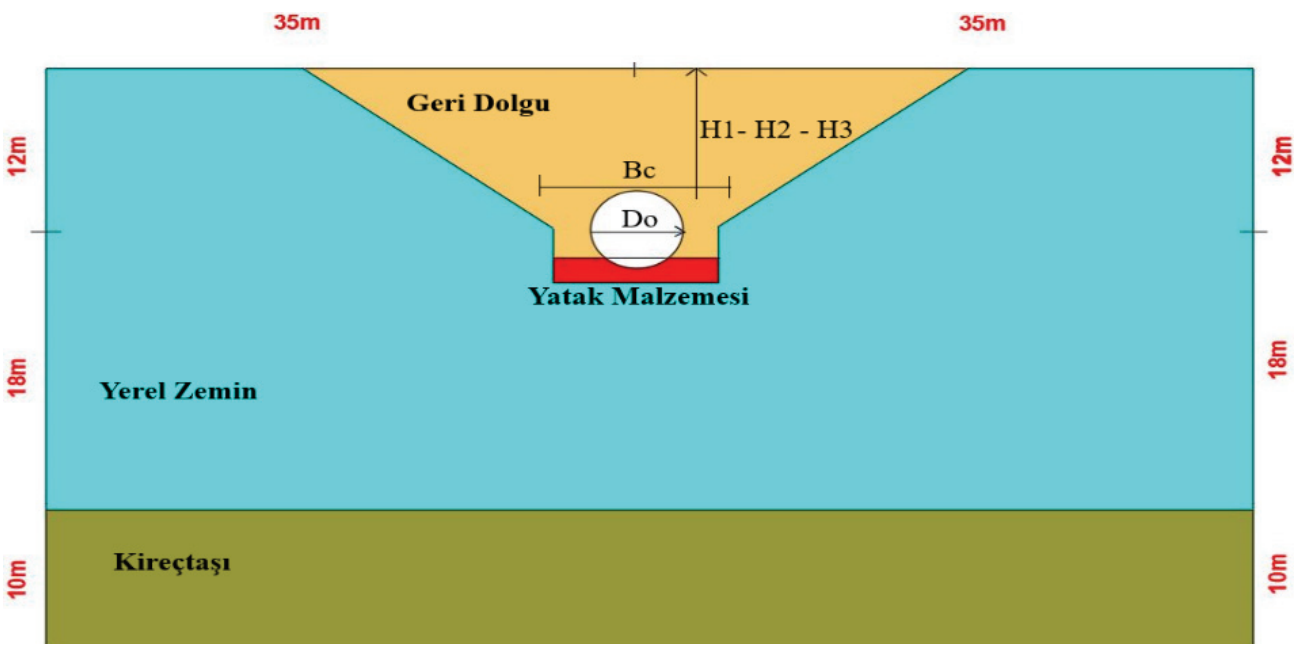

Şekil 4 - Problem model geometrisi 
Tablo 6 - Sayısal analizlerde kullanılan zemin özellikleri

\begin{tabular}{|c|c|c|c|c|c|c|c|}
\hline Zemin Tipi & $\begin{array}{c}\gamma \\
\left(k N / m^{3}\right)\end{array}$ & $\begin{array}{l}\text { E50 }^{\text {ref }} \\
(\mathrm{MPa})\end{array}$ & $\begin{array}{l}\text { Eoed }^{\text {ref }} \\
(\mathrm{MPa})\end{array}$ & $\begin{array}{l}\text { Eur }^{\text {ref }} \\
\text { (MPa) }\end{array}$ & $\begin{array}{c}c^{\text {'ref }} \\
(\mathbf{k P a})\end{array}$ & $\begin{array}{c}\phi \\
\left(^{\circ}\right)\end{array}$ & $\begin{array}{c}\mathbf{E} \\
(\mathbf{M P a})\end{array}$ \\
\hline Yatak (HS) & 17 & 10 & 10 & 30 & 5 & 25 & - \\
\hline Yerel Zemin (HS) & 19 & 20 & 20 & 60 & 10 & 32 & - \\
\hline Geri Dolgu 1(HS) & 18 & 15 & 15 & 45 & 5 & 32 & - \\
\hline Geri Dolgu 2(HS) & 20 & 15 & 15 & 45 & 10 & 32 & - \\
\hline Geri Dolgu 3(HS) & 23 & 20 & 20 & 60 & 10 & 32 & - \\
\hline Kireçtaşı (MC) & 24 & - & - & - & 50 & 35 & $15 \times 10^{3}$ \\
\hline
\end{tabular}

Not: HS Pekleşen Zemin, MC Mohr Coulomb, $\gamma$ Zemin Birim Hacim Ağırlığı, E Elastisite Modülü, $\mathrm{E}_{50}{ }^{\mathrm{ref}}$ Referans Elastisite Modülü, E oed $^{\text {ref }}$ Referans Ödometre Modülü, Eur ${ }^{\text {ref }}$ Referans Yükleme Boşaltma Modülü, c'ref Kohezyon, $\phi$ İçsel Sürtünme Açısı, *vur (Poisson Oran1) 0.2, *Kireçtaş1 0.3.

Çalışmada, dolaylı tasarım yöntemi için geometri, kurulum tipi ve boru çaplarına bağlı olarak minimum yataklama faktörleri $\left(\mathrm{Bf}_{\mathrm{o}}\right)$, yatak katsayıları $\left(\mathrm{Bf}_{\mathrm{e}}\right)$ ve ana yatak katsayıları $\left(\mathrm{Bf}_{\mathrm{v}}\right)$ Beton Boru Tasarım Rehberi (ACPA, 2011)'den alınmıştır (Tablo 7). Problemde hendek genişliği 3.5m'dir. Doğrudan tasarım yöntemi için borunun taban, yan duvar ve taç bölgeleri için boru tabanından itibaren taban bölgesi $0^{\circ}$, yan duvar bölgesi $90^{\circ}$, taç bölgesi $180^{\circ}$ olmak üzere bu açılara denk gelen eksenel kuvvet, kesme kuvveti ve moment hesap katsayıları ASCE 15-98 Şartnamesinden alınmıştır.

Tablo 7 - Dolayl tasarım yönteminde kurulum tipleri ve yataklama katsayıları [17]

\begin{tabular}{cccc}
\hline $\begin{array}{c}\text { Standart } \\
\text { Kurulum Tipleri }\end{array}$ & $\begin{array}{c}\text { Minimum Yataklama } \\
\text { Katsayısı }\left(\mathbf{B f}_{\mathbf{o}}\right)\end{array}$ & $\begin{array}{c}\text { Yataklama } \\
\text { Katsayısı }\left(\mathbf{B f}_{\mathbf{e}}\right)\end{array}$ & $\begin{array}{c}\text { Ana Yataklama } \\
\text { Katsayısı }\left(\mathbf{B f}_{\mathbf{v}}\right)\end{array}$ \\
\hline Tip 1 (T1) & 2.3 & 3.76 & $2.74-3.62$ \\
\hline Tip 2 (T2) & 1.9 & 2.8 & $2.17-2.71$ \\
\hline Tip 3 (T3) & 1.7 & 2.2 & $1.85-2.15$ \\
\hline Tip 4 (T4) & 1.5 & 1.7 & $1.56-1.68$ \\
\hline
\end{tabular}

\subsection{Konvansiyonel Yöntemler ile Hesaplamalar}

\subsubsection{Dolaylı Tasarım Yöntemi}

Dolgu yüksekliğinin ve zemin birim hacim ağırlığının çatlama D-Yüküne olan etkisini hesaplamak için, Tip 1 standart yükleme koşulları dikkate alınarak yapılan analizlerde boru iç çap1 $1.5 \mathrm{~m}$ ve et kalınlığ $0.2 \mathrm{~m}$ olarak sabit tutularak, dolgu yükseklikleri H1, H2 ve H3 sirasiyla 3m, 6m ve 12m'dir. Grup 1 (G1), Grup 2 (G2) ve Grup 3 (G3) sirasiyla 18, 20 ve $23 \mathrm{kN} / \mathrm{m}^{3}$ zemin birim hacim ağırlıklarını ifade ederken, artan dolgu yüksekliklerinin çatlama D-Yüküne olan etkisi incelenmiştir (Şekil 5). Şekil 5a'da Grup 1 için H1, H2 ve H3 örtü 
derinliklerinde sırasıyla 33, 62 ve 102.5 kN/m/m D-Yükleri hesaplanmıştır. Grup 2 ve Grup 3 için aynı derinliklerde sırasıyla 37, 67 ve $113.9 \mathrm{kN} / \mathrm{m} / \mathrm{m}$ ve 42,77 ve $131 \mathrm{kN} / \mathrm{m} / \mathrm{m}$ çatlama D-Yükleri elde edilmiştir. Görüldügüü gibi, hesaplanan en yüksek D-Yükleri kıyaslandığında G3 zemin grubundaki kurulumda G2 ve G1'e göre sırasıyla \%15 ve \%28 daha fazladır. Dolaylı tasarım yönteminde, dolgu yüksekliği arttıkça $(\mathrm{H} 1$ - H2 - H3) betonarme boruda oluşan çatlama D-Yüklerinde artış meydana gelmiştir. Ayrıca, aynı dolgu yüksekliğinde zemin birim hacim ağırlığındaki artış (G1 - G2 - G3) nedeniyle D-Yüklerinin az da olsa arttığ1 belirlenmiştir. Zemin birim hacim ağırlığındaki artışın (Şekil 5b) D-Yüklerini artırdığı ve artış oranının dolgu yüksekliği arttıkça daha fazla oranda gerçekleştiği tespit edilmiştir. Şekil 5b'den görüldüğü gibi D-Yüklerindeki artış, H3 dolgu yüksekliğindeki kurulumda H2 ve H1'e göre sirasıyla \%69 ve \%311 daha fazladır.

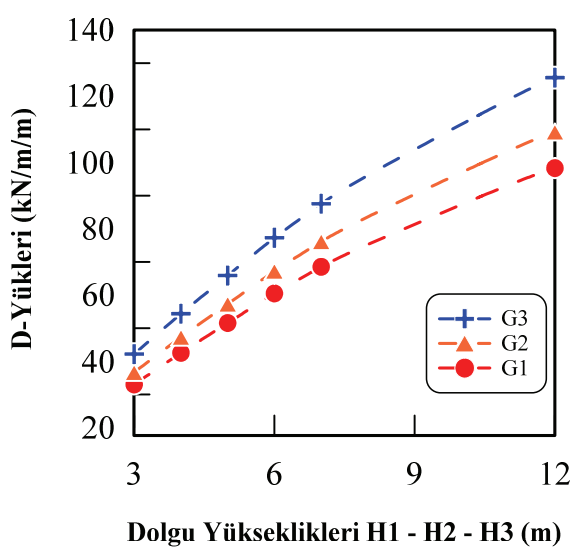

(a)

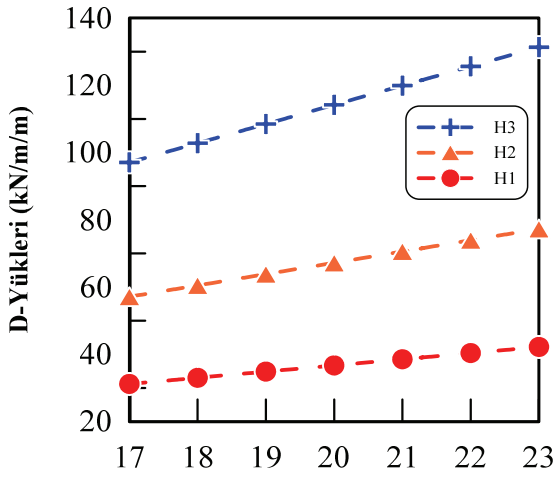

Zemin Birim Hacim Ağırlıkları G1 - G2 - G3 (kN/m³) (b)

Şekil 5 - a) Dolgu Yüksekliklerindeki Değişimin D-Yüklerine Etkisi, b) Zemin Birim Hacim Ağırlıklarındaki Değişimin D-Yüklerine Etkisi

H1, H2 ve H3 dolgu yükseklikleri için boru iç çapları (Di) $0.6 \mathrm{~m}$ ve $1.6 \mathrm{~m}$ arasında kademeli olarak arttırılarak, farklı dolgu yükseklikleri ve boru iç çapındaki değişimlerin çatlama DYüklerine olan etkisi incelenmiştir. Şekil 6a'da gösterildiği gibi, betonarme boru iç çaplarının artmasının borudaki çatlama D-Yüklerini azalttığı görülmektedir. $0.6 \mathrm{~m}$ iç çapa sahip betonarme boruda D-Yükleri, H1 ve $\mathrm{H} 2$ dolgu yüksekliklerinde boru çatlama D-Yükleri kabul edilebilir seviyelerde iken, H3 dolgu yüksekliğinde ise $310 \mathrm{kN} / \mathrm{m} / \mathrm{m}$ gibi çok yüksek bir değere çıkmıştır. H3 dolgu yüksekliğinde boru çap1 $0.6 \mathrm{~m}$ 'den $1.6 \mathrm{~m}$ 'ye yükseltildiğinde azalış oranı $\% 58$ iken, $\mathrm{H} 2$ dolgu yüksekliğinde $\% 57$ ve $\mathrm{H} 1$ dolgu yüksekliğinde ise $\% 56$ 'dır. Böylece, dolaylı tasarım yönteminde nispeten yüksek dolgular altında kalacak betonarme boruların çapları 1m'den az olmaması gerektiği tespit edilmiştir. Ayrıca, yüksek dolgu yüklerine maruz kalacak boruların çap artışına bağlı olarak D-Yüklerindeki azalma oranının düşük dolgu yüklerine göre daha fazla olduğu belirlenmiştir.

H1, H2 ve H3 dolgu yüksekliklerini belirtirken, değişken yataklama katsayılarının boruda oluşan çatlama D-Yüklerine olan etkisini incelemek için analizler yapılmıştır. Analizlerde standart kurulum tipi T1 olup minimum yataklama faktörü $\left(\mathrm{B}_{\mathrm{fo}}=2.3\right)$, boru iç çap $2 \mathrm{~m}$, boru et kalınlığı $0.2 \mathrm{~m}$ ve hendek genişliği $3.5 \mathrm{~m}$ olarak alınmıştır. Yataklama katsayıları $\left(\mathrm{B}_{\mathrm{fe}}\right) 3 \mathrm{ve}$ 
3.9 arasında kademeli olarak artırılmış ve hesap sonuçları Şekil 6b'de sunulmuştur. Görüldüğü gibi yataklama katsayıları kademeli olarak arttıkça boruda meydana gelen çatlama D-Yüklerinde azalma meydana gelmiştir. Bu azalmanın oranı H3 dolgu yüksekliğinde $\% 14, \mathrm{H} 2$ dolgu yüksekliğinde $\% 17, \mathrm{H} 1$ dolgu yüksekliğinde ise $\% 19.5$ 'tir.

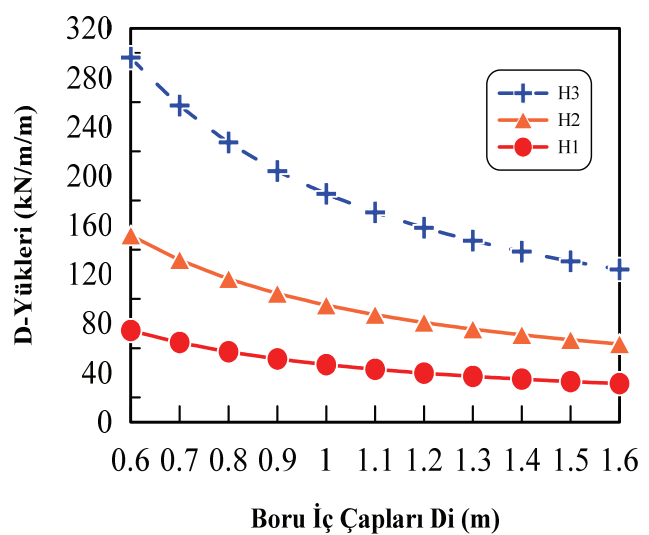

(a)

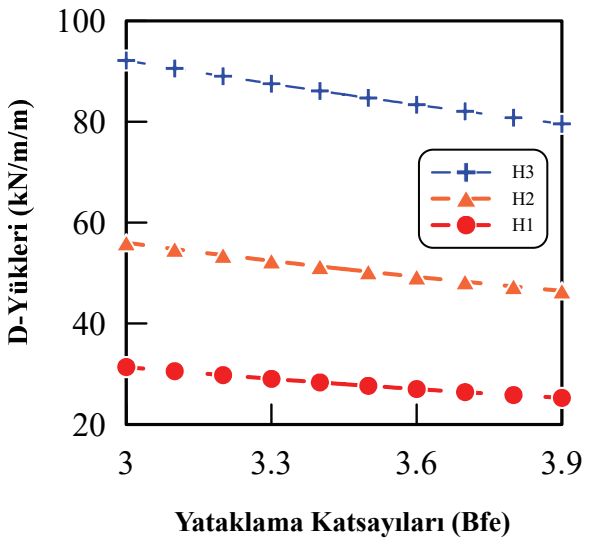

(b)

Şekil 6 - a) Boru İç Çapı Değişimin D-Yüklerine Olan Etkisi, b) Yataklama Katsayısı Değişimin D-Yüklerine Olan Etkisi

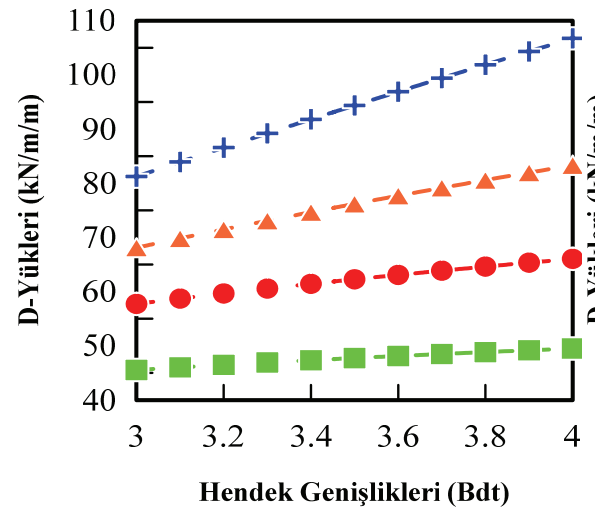

(a)

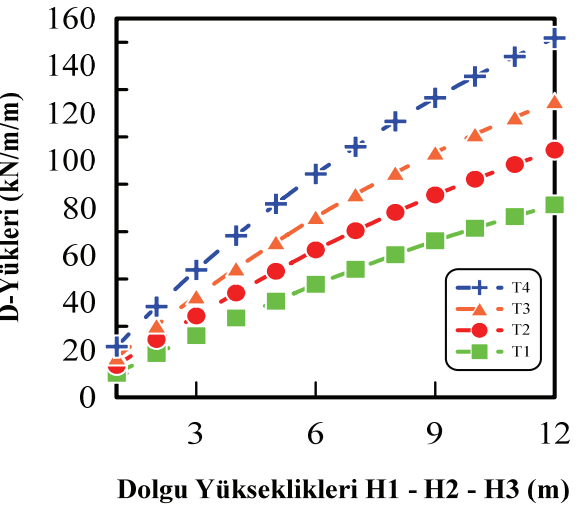

(b)

Şekil 7 - a) Hendek Genişliği ve Kurulum Tipindeki Değişimin D-Yüklerine Etkisi, b) Dolgu Yüksekliği ve Kurulum Tipindeki Değişimin D-Yüklerine Etkisi

Dolaylı tasarım yönteminde Tip 1, 2, 3 ve 4 boru kurulumlarında hendek genişliği değişiminin D-Yüklerine olan etkileri incelenmiştir. Analizler, H2 $(6 \mathrm{~m})$ dolgu yüksekliği dikkate alınarak ve $18 \mathrm{kN} / \mathrm{m}^{3}$ zemin birim hacim ağırlığına sahip olan G1 zemin için yapılmıştır. Hendek genişlikleri $\left(\mathrm{B}_{\mathrm{dt}}\right)$ ise $3 \mathrm{~m}$ ve $4 \mathrm{~m}$ arasında değişim göstermekte ve boru iç çapı $2 \mathrm{~m}$, duvar kalınlığ 1 ise $0.2 \mathrm{~m}$ olarak alınmıştır (Şekil 7). Şekil 7a'da, tüm kurulum 
tiplerinde hendek genişliği arttıkça D-Yüklerinde artış meydana gelmiş ve bu artış oranı Tip 1 kurulumda \%8, Tip 2 kurulumda \%15.7, Tip 3 kurulumda \%22.3 ve Tip 4 kurulumda yaklaşık \%30'dur. H1, H2 ve H3 dolgu yüksekliklerini belirtirken, boru kurulumunda standart kurulum tiplerindeki (T1- T4) farklılıklarının borudaki çatlama D-Yüklerine olan etkisi analiz edilmiş ve sonuçları Şekil 7b'de gösterilmiştir. Dolgu yüksekliğindeki artışın borudaki çatlak D-Yüklerini artırdığı ve aynı zamanda Tip 1'den 4'e doğru boru kurulum tipi değiştirildiğinde borudaki çatlama D-Yüklerinde de artış olduğu tespit edilmiştir. Tip 1'den Tip 4 kuruluma doğru H1, H2 ve H3 dolgu yükseklikleri için sırasıyla \%106, \%97 ve \%86 oranlarında artış meydana gelmiştir.

\subsubsection{Doğrudan Tasarım Yöntemi}

Doğrudan tasarım yönteminde dolgu yüksekliğinin boru kesitinde oluşan iç kuvvetlere olan etkisini belirlemek için, Tip 1 kurulumda Grup 1 (G1) $18 \mathrm{kN} / \mathrm{m}^{3}$ birim hacim ağırlığında zemin kullanılmış, boru iç çapı $1.5 \mathrm{~m}$ ve et kalınlığ $0.2 \mathrm{~m}$ olarak sabit tutulmuş ve dolgu yükseklikleri H1, H2 ve H3 için hesaplar yapılmıştır. Elde edilen eğilme momenti, eksenel kuvvet ve kesme kuvveti değerleri sırasıyla Şekil 8a, b ve c'de sunulmuştur. Şekil 8'de, dolgu yüksekliği artışının eğilme momenti, eksenel kuvveti ve kesme kuvveti değerlerini artırdığ1 ve en yüksek eğilme momenti değerinin boru tabanında $\left(0^{\circ}\right)$, en yüksek eksenel kuvvet değerinin ise borunun yan duvarında $\left(90^{\circ}\right)$ oluştuğu tespit edilmiştir. Eğilme momenti artış oranına bakıldığında dolgu yükseklikleri H1'den H3'e artırıldığında borunun taban bölgesinde yaklaşık \%281'lik bir artış hesaplanmıştır (Şekil 8a). Şekil 8b'de gösterilen eksenel kuvvet değerleri incelendiğinde, borunun taban bölgesinde $\left(0^{\circ}\right)$ sirasıly $3 \mathrm{~m}, 6 \mathrm{~m}$ ve $12 \mathrm{~m}$ dolgu yüksekliklerinde, sırasıyla $26 \mathrm{kN} / \mathrm{m}, 51 \mathrm{kN} / \mathrm{m}$ ve $100 \mathrm{kN} / \mathrm{m}$ değerlerine kadar artmıştır. En yüksek eksenel kuvvet değeri borunun yan duvar bölgesinde $281 \mathrm{kN} / \mathrm{m}$ olarak hesaplanmıştır. Borunun taç bölgesinde $\left(180^{\circ}\right)^{\prime}$ de ise $3 \mathrm{~m}, 6 \mathrm{~m}$ ve $12 \mathrm{~m}$ dolgu yüksekliklerinde sırasıyla $22 \mathrm{kN} / \mathrm{m}, 44 \mathrm{kN} / \mathrm{m}$ ve $86 \mathrm{kN} / \mathrm{m}$ olarak elde edilmiştir. Böylece doğrudan tasarım yönteminde, boru üzerindeki dolgu yüksekliği arttıkça eksenel kuvvet değerlerinde de artış olduğu tespit edilmiştir. Eksenel kuvvetlerin artış oranına bakıldığında borunun yan duvar bölgesinde dolgu yükseklikleri H1'den H3'e artırıldığında yaklaşık \%270'lik bir artış belirlenmiştir. Şekil 8c'de borunun taban ve taç bölgesinde $\left(0^{\circ}, 180^{\circ}\right)$ kesme kuvveti değeri oluşmadığ1, borunun yan duvar bölgesine $\left(90^{\circ}\right)$ doğru gidildiğinde ise kesme kuvveti değerlerinde artış meydana gelmiştir. Yan duvar bölgesinde 26.48 kN/m'lik kesme kuvveti oluşmuş ve en yüksek kesme kuvveti değeri $120^{\circ}$ 'lik açıda $100 \mathrm{kN} / \mathrm{m}$ olarak hesaplanmıştır. Dolgu yüksekliklerindeki artış kesme kuvveti değerlerini de artırmıştır.

Doğrudan tasarım yönteminde G1, G2 ve G3 zemin birim hacim ağırlıklarını ifade ederken, Şekil 9'da artan dolgu yüksekliğine karşılık gerekli donatı alanlarındaki değişim gösterilmiştir. Dolgu yüksekliği arttığında gerekli donatı alanlarında da artış meydana gelmiştir. Bu artışın oranı, $\mathrm{H} 3$ dolgu yüksekliğinde $\% 37, \mathrm{H} 2$ dolgu yüksekliğinde $\% 36.2, \mathrm{H} 1$ dolgu yüksekliğinde ise $\% 35$ 'tir.

Doğrudan tasarım yönteminde zemin birim hacim ağırlıklarının boru kesitinde oluşan iç kuvvetlere olan etkisi, Tip 1 kurulumda boru iç çap $1.5 \mathrm{~m}$ ve et kalınlığ $10.2 \mathrm{~m}$ sabit tutularak incelenmiştir. Şekil 10a, Şekil 10b ve Şekil 10c'de birim hacim ağırlık değişiminin sırasıyla moment, normal kuvvet ve kesme kuvvetine etkileri sunulmuştur. Şekil 10a'da, en yüksek eğilme momenti beklendiği gibi borunun taban bölgesinde oluşmuş ve eğilme momenti 
değerlerinin zeminin birim hacim artışına bağlı olarak değişim gösterdiği tespit edilmiştir. G1 zemin grubundan G3 zemin grubuna değişimde borunun taban bölgesinde elde edilen eğilme momentlerinde \%27'lik bir artış olmuştur. Şekil 10b'de, borunun taban bölgesinde $\left(0^{\circ}\right) \mathrm{G} 1$ zemin grubunda $26 \mathrm{kN} / \mathrm{m}$ eksenel kuvvet hesaplanırken, G2 zemin grubunda bu değer $29 \mathrm{kN} / \mathrm{m}$ ve G3 zemin grubunda ise $33.8 \mathrm{kN} / \mathrm{m}$ 'dir. En yüksek eksenel kuvvet değeri borunun yan duvar bölgesinde $\left(90^{\circ}\right) \mathrm{G} 3$ zemin grubunda $94.5 \mathrm{kN} / \mathrm{m}$ olarak hesaplanmıştır. Yan duvarda en yüksek değerden boru taç bölgesine doğru gidilirken eksenel kuvvet değerleri hızlıca azalmıştır. G1 zemin grubundan G3 zemin grubuna değişimde borunun yan duvar bölgesinde elde edilen eksenel kuvvetlerde \%28'lik bir artış meydana gelmiş ve eksenel kuvvet değerlerinin zemin birim hacim ağırlığı artışıyla doğru orantılı olarak artış gösterdiği belirlenmiştir. Şekil $10 c^{\prime}$ de, borunun taban ve taç bölgesinde $\left(0^{\circ}, 180^{\circ}\right)$ kesme kuvveti değeri görülmezken, en yüksek kesme kuvveti değeri borunun tabanından yaklaşık $\left(125^{\circ}\right)^{\prime}$ lik açıda G3 zemin grubunda $33.8 \mathrm{kN} / \mathrm{m}$ olarak hesaplanmıştır.

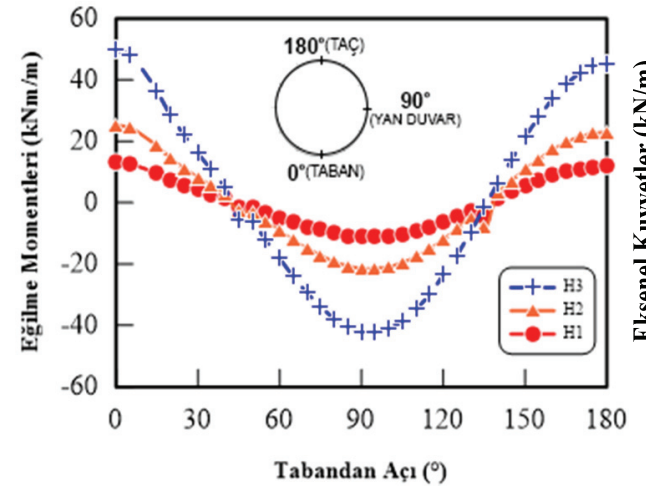

(a)

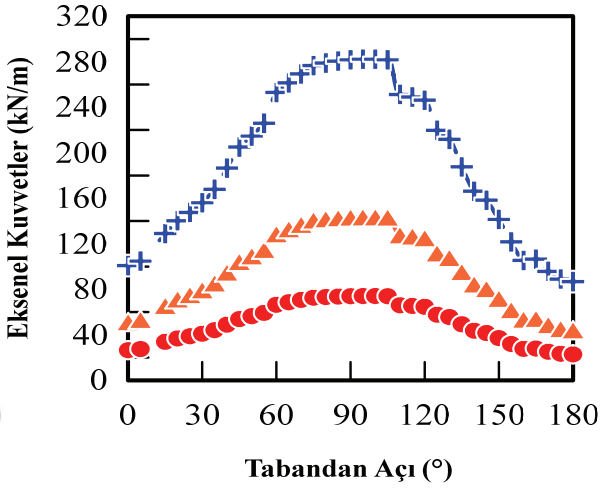

(b)

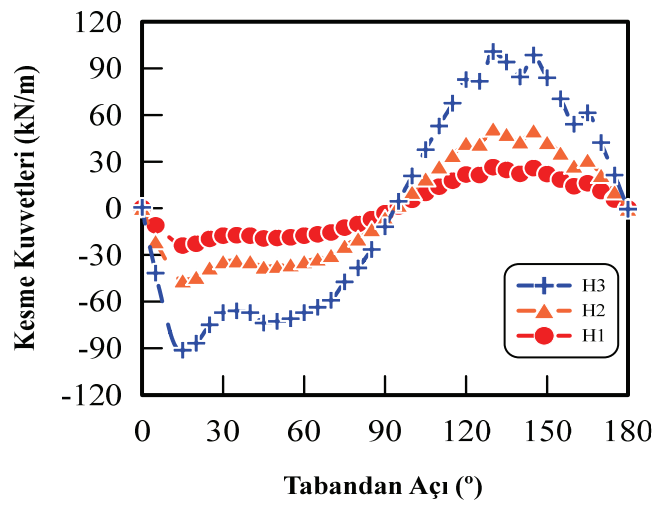

(c)

Şekil 8 - Dolgu Yüksekliği Etkisi a) Eğilme Momenti, b) Eksenel Kuvvet, c) Kesme Kuvveti 


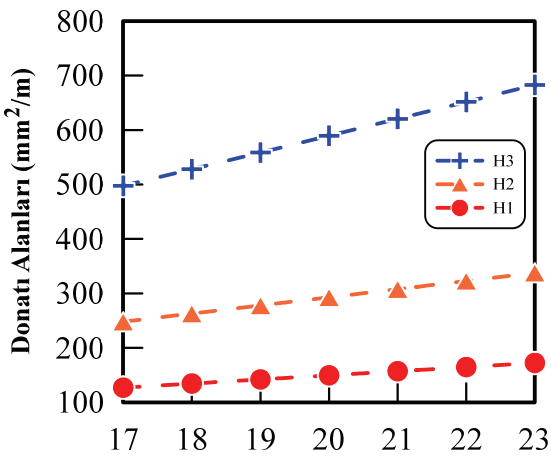

Zemin Birim Hacim Ağırlıkları G1 - G2 - G3 (kN/m³)

Şekil 9 - Dolgu Yüksekliğinin Gerekli Donatı Alanına Etkisi

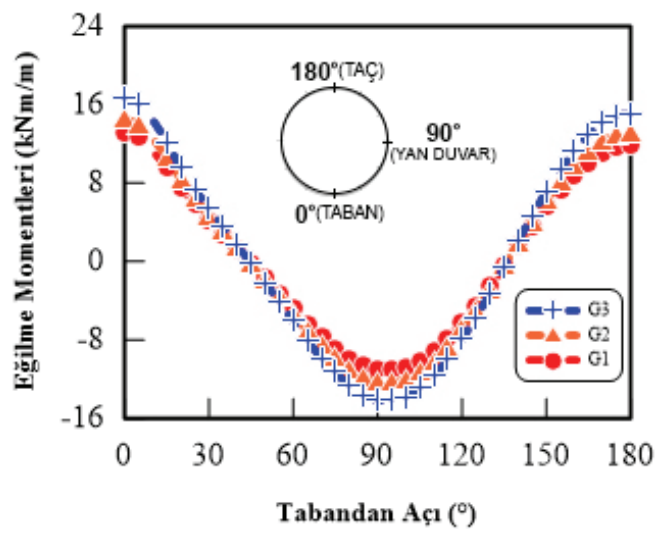

(a)

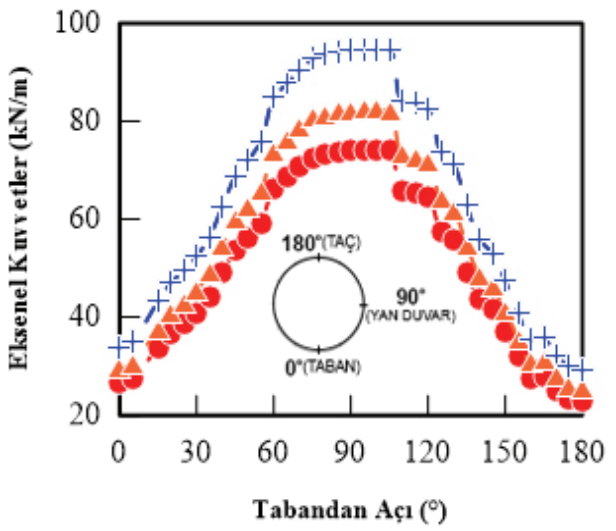

(b)

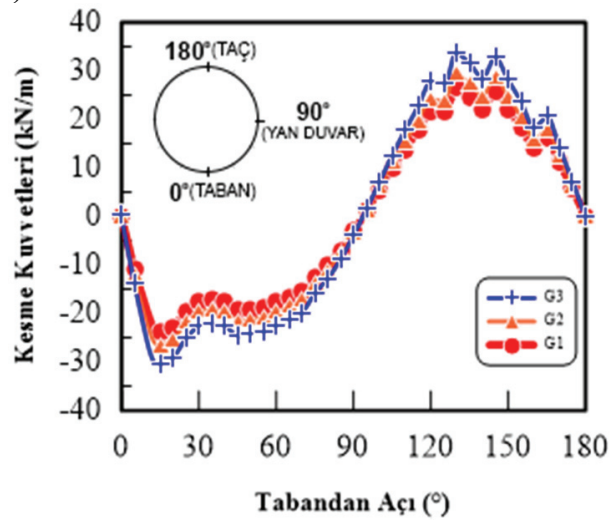

(c)

Şekil 10 - Zemin Birim hacim ă̆ırlı̆̆ı değişimi etkileri a) Ĕ̆ilme Momenti, b) Eksenel Kuvvet, c) Kesme Kuvveti 


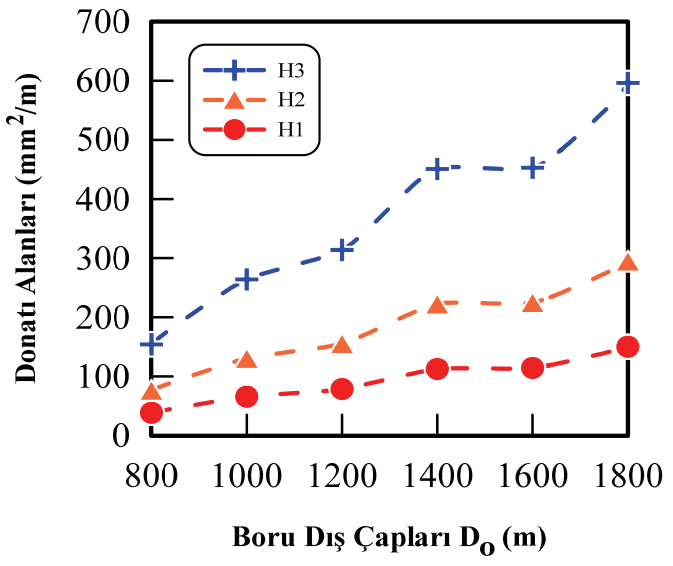

Şekil 11 - Boru Dış Çapı Değişimin Gerekli Donatı Alanına Etkisi

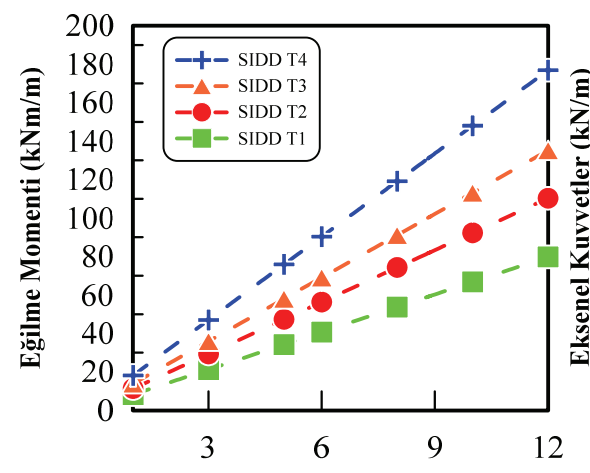

Dolgu Yükseklikleri H1 - H2 - H3 (m)

(a)

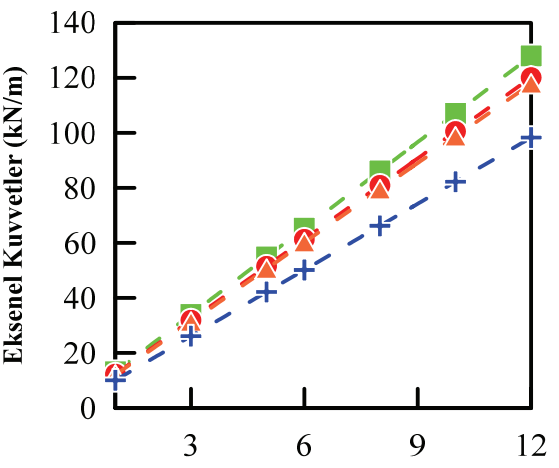

Dolgu Yükseklikleri H1 - H2 - H3 (m)

(b)

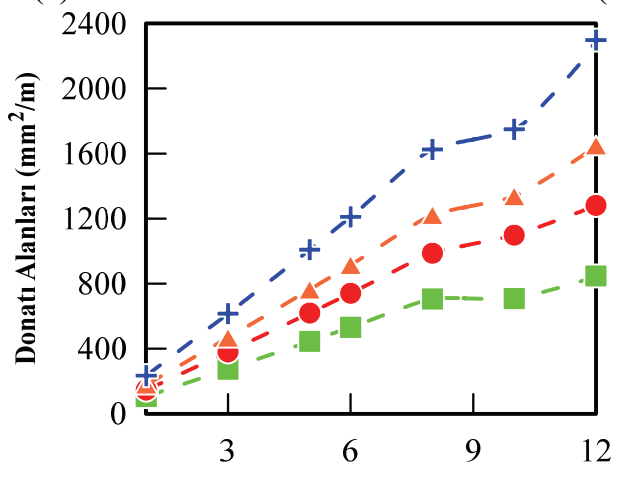

Dolgu Yükseklikleri H1 - H2 - H3 (m)

(c)

Şekil 12 - SIDD Kurulum Tiplerine Göre a) Eğilme Momenti b) Eksenel Kuvvet c) Gerekli Donatı Alanı 
Doğrudan tasarım yönteminde H1 dolgu yüksekliğinde ve $1.5 \mathrm{~m}$ iç çaplı boru kullanılarak yapılan analizlerde, G1, G2 ve G3 zemin birim hacim ağırlıklarını ifade ederken birim hacim ağırlığı artışııın, gerekli donatı alanlarını da arttığı tespit edilmiştir (Şekil 11).

Doğrudan tasarım yönteminde tasarımlarda, boruların dış çapı arttıkça gerekli donatı alanı ihtiyacı da artmaktadır. SIDD'de Heger toprak basıncı dağılımlarını (Şekil 2) belirlerken düşey kemerlenme faktörü (VAF) Standart Kurulum Tipleri (T1-T4)'ne göre değişmektedir. Analizlerde düssey kemerlenme faktörü VAF, $\mathrm{T} 1$ için 1.35 , T2 ve T3 için 1.40, T4 için ise 1.45 alınmıştır (Tablo 4). Boru iç çapı $2 \mathrm{~m}$ ve G1 zemin için H1, H2 ve H3 dolgu yükseklikleri dikkate alınarak yapılan analizlerin sonuçlarına göre kesit tesirleri hesaplanmış ve Şekil 12'de sunulmuştur. SIDD Tip 1'den Tip 4'e doğru kurulum tiplerine göre eğilme momenti, normal kuvvet ve donatı alanı değişimleri sırasıyla Şekil 12a, Şekil 12b ve Şekil 12c'de sunulmuştur. Şekil 12a'da SIDD Tip 1'den Tip 4'e doğru kurulum doğru eğilme momentlerinin arttığı görülmektedir. Tip 1'den Tip 4 kuruluma geçildiğinde H1, H2 ve H3 dolgu yükseklikleri için artış oranı sırasıyla $\% 122, \% 121$ ve \%120'dir. Şekil 12 b'de eksenel kuvvetler SIDD Tip 1'den Tip 4 kuruluma doğru azalmaktadır. Tip 1'den Tip 4 kuruluma geçildiğinde $\mathrm{H} 3$ dolgu yüksekliğinde eksenel kuvvetlerde $\% 23$ oranında bir azalma meydana gelmiştir. Fakat bu azalışın Tip 2 ve 3 arasında $\% 1.85$ oranında olduğu görülmüştür. Bunun sebebi ise her iki tip kurulumda da düşey kemerlenme faktörleri (VAF) değeri 1.40'tır. Şekil 12c'de SIDD Kurulum Tipi 1'den Tip 4'e doğru gerekli donatı alanının arttığı belirlenmiştir. Tip 1'den Tip 4 kuruluma doğru gerekli donatı alanlarında H1, H2 ve H3 dolgu yüksekliklerinde sırasıyla $\% 124, \% 128$ ve $\% 171$ oranlarında artış hesaplanmıştır.

\subsection{Sayısal Analizler}

Hendek ortamında gömülü betonarme boru için Şekil 4'te gösterilen model geometrisi dikkate alınarak ve Tablo 5 ve 6 'da verilen malzeme parametreleri kullanılarak sayısal analizler yapılmıştır. Analizlerde H1-H2-H3 dolgu yükseklikleri, G1-G2-G3 geri dolgu zeminin birim hacim ağırlıkları ve Ø800-Ø1800mm aralığında boru çapı değişimlerinin etkileri incelenmiştir. Beton borunun taban, taç ve yan duvar bölgelerindeki eğilme momenti, eksenel ve kesme kuvvetleri ve gerekli donatı alanı ihtiyaçları yapılan parametrik sayısal analizlerden hesaplanmıştır. Şekil 13'te sayısal analizlerde kullanılan zemin-boru etkileşim probleminin sonlu elemanlar ağı gösterilmiş̧tir. Dolgu yüksekliklerinin ve zemin grubundaki değişimlerinin hesap sonuçları Şekil 14'te sunulmuştur. Sayısal analiz sonuçlarının analitik analizlerle karşılaş̧ırıllması Tablo 8 ve 9'da verilmiştir.

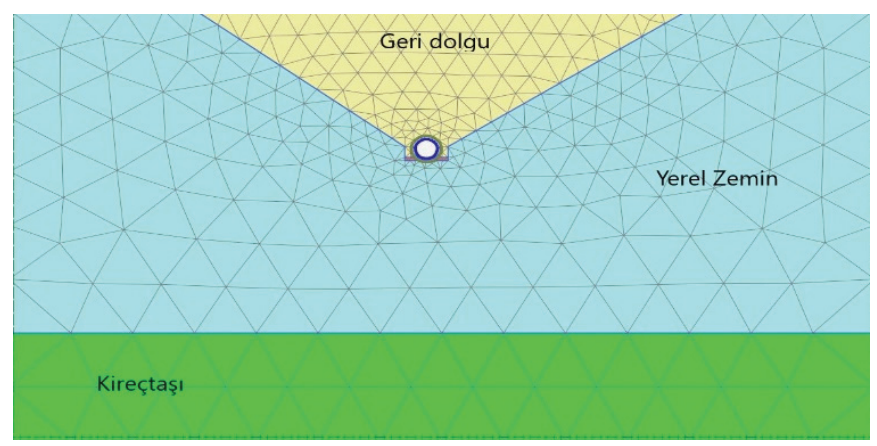

Şekil 13 - Saylsal analiz modeli 
Dolgu yükseklikleri H1'den H3'e artırıldığında Şekil 14a'da eğilme momenti artışı borunun taban bölgesinde yaklaşık olarak \%173 ve Şekil 14b'de eksenel kuvvet yan duvar bölgesinde yaklaşık \%194 olarak hesaplanmıştır. Şekil 14c'de en yüksek eğilme momenti beklendiği gibi borunun taban bölgesinde oluşmuştur. Eğilme momenti değerlerinin zeminin birim hacim artışına bağlı olarak değişim gösterdiği tespit edilmiştir. G1 zemin grubundan G3 zemin grubuna değişimde borunun taban bölgesinde elde edilen eğilme momentlerinde \%9'luk bir artış meydana gelmiştir. Şekil 14d'de en yüksek eksenel kuvvet değeri borunun yan duvar bölgesinde $\left(90^{\circ}\right)$ G3 zemin grubunda $82.4 \mathrm{kN} / \mathrm{m}$ olarak hesaplanmış ve boru taç bölgesine doğru gidilirken eksenel kuvvet değerleri hızlıca azalmıştır. Böylece, dolgu yüksekliği artışının eğilme momenti, eksenel kuvvet ve kesme kuvveti değerlerini artırdığı ve en yüksek eğilme momenti değerinin boru tabanında $\left(0^{\circ}\right)$, en yüksek eksenel kuvvet değerinin ise borunun yan duvar bölgesinde $\left(90^{\circ}\right)$ oluştuğu tespit edilmiştir. G1 zemin grubundan G3 zemin grubuna değişimimde borunun yan duvar bölgesinde eksenel kuvvetlerde \%22'lik bir artış hesaplanmıştır. Sayısal analizlerde boru bölgelerindeki iç kuvvetlerin dolgu yükseklikleri ve zemin gruplarına bağlı olarak değişim etkilerinin SIDD (Doğrudan tasarım) yöntemine göre yüzdesel olarak daha düşük olduğu tespit edilmişstir.

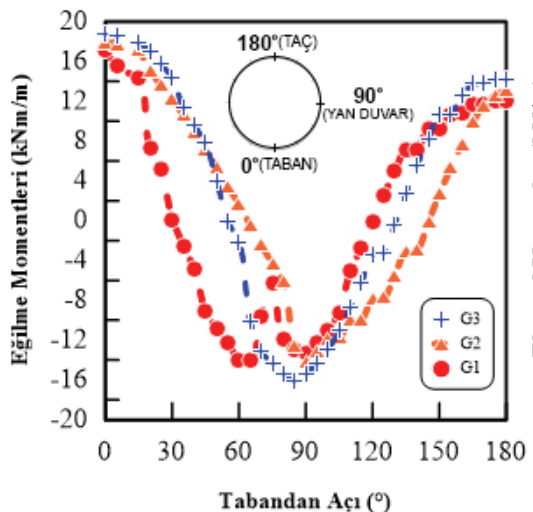

(a)

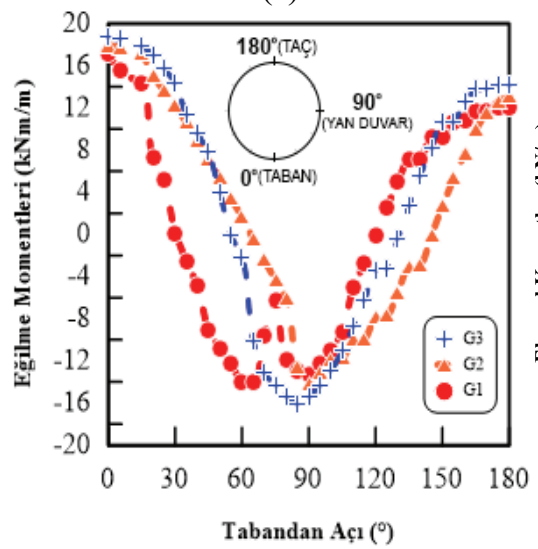

(c)

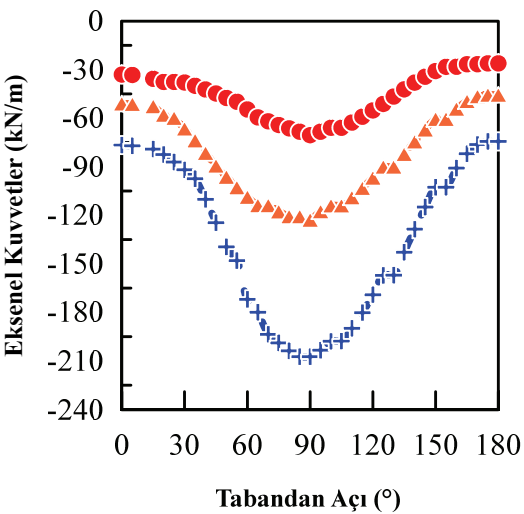

(b)

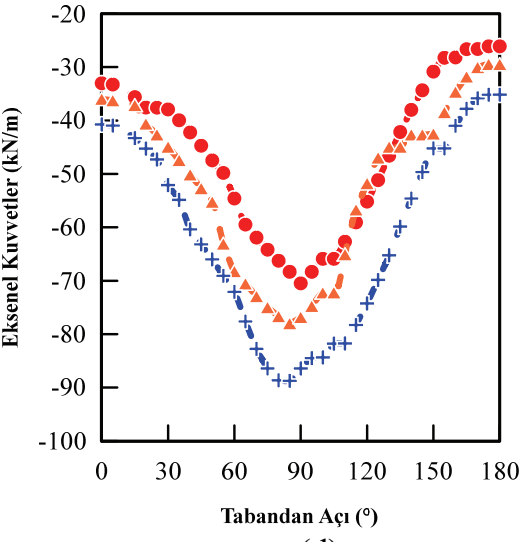

(d)

Şekil 14 - Sayısal analiz sonuçları a) dolgu yüksekliği - momentler b) dolgu yüksekliği eksenel kuvvetler c) zemin grubu - momentler d) zemin grubu-eksenel kuvvetler 


\subsection{Yöntemlerin Karşılaştırması}

Günümüzde yaygın olarak boru tasarımında kullanılan geleneksel yöntemlerin (dolaylı ve doğrudan tasarım) ne kadar konservatif davrandığını incelemek için sayısal analizlerden elde edilen hesap sonuçları ile kıyaslanmıştır. Dolaylı tasarım yöntemi yaklaşık 70 yıldır uygulanan ampirik bir yöntemdir ve bu yöntem kolay uygulanabilirliğe sahip olduğundan günümüzde yaygın olarak kullanılmaktadır. Doğrudan tasarım yöntemi ise limit durum tasarımının uygulandığı, Heger basınç dağılımlarının kullanıldığ 1 ve 1970'li yılların çeşitli bilgisayar yazılımları (SPIDA) ile geliştirilen daha az ampirik bir yöntemdir. Bu yöntemlerin günümüzde kabul edilebilirliğinin sorgulanması ve avantaj/dezavantajlarının sofistike sonlu elemanlar yöntemleri ile kıyaslanması ekonomi ve fizibilite açısından gerekmektedir. Çalışma sonucunda elde edilen veriler literatür kısmında verilen çalışmalardaki sonuçlar ile uyumludur.

Doğrudan tasarım yöntemi ile hesaplanan iç kuvvet değerleri Tip 1 standart kurulum içindir ve dolayısıyla sayısal analizlerde de sağlıklı bir kıyaslama için bu kurulum tipine göre malzeme özellikleri seçilmiş ve analizler yapılmıştır. Farklı bir kurulum tipi olan Tip 4 kurulum ile gömülü betonarme boru tasarımı için Kılıç ve Demirci (2022)'de analitik yöntemler ve sayısal analiz sonuçları karşılaştırılarak parametrik bir çalışma yapılmıştır [18]. Sayısal analiz (sonlu elemanlar yöntemi) ile analitik analiz (dolaylı ve doğrudan tasarım yöntemi) sonuçlarının karşılaştırılması Tablo 8 ve 9'da sunulmuştur. Analiz sonuçları en yüksek iç kuvvetleri ve donatı alanlarını veren $\mathrm{H} 3$ dolgu yüksekliğinde değerlendirilmiştir. Tablo 8, 9 ve Şekil 15 incelendiğinde, dolaylı tasarım yöntemi ve doğrudan tasarım yöntemlerinin sayısal analizlere göre konservatif sonuçlar verdiği tespit edilmiştir.

Dolaylı tasarım yöntemi dikkate alınarak yapılan parametrik analizlere göre elde edilen DYüklerine göre ASTM C76 Şartnamesinden gerekli boru sınıfları ve donatı alanları belirlenmiştir. Şekil 6 a ve Şekil 15 'te görüldüğü gibi dolaylı tasarım yönteminde $1.8 \mathrm{~m}$ dış çapa sahip boruda $136.7 \mathrm{kN} / \mathrm{m} / \mathrm{m}^{\prime}$ 'lik D-Yüküne karşılık gelen boru sınıfı IV olarak seçilmiş ve buna karşılık gelen gerekli donatı alanı $8.7 \mathrm{~cm}^{2} / \mathrm{m}=870 \mathrm{~mm}^{2} / \mathrm{m}$ olarak belirlenmiştir (ASTM C76 M-05, Tablo 5).

Tablo 8 - Boru bölgelerindeki iç kuvvetlerin farklı analiz yöntemleri ile karşılaştırılması

\begin{tabular}{ccccccccc}
\hline \multirow{2}{*}{$\begin{array}{c}\text { İç } \\
\text { Kuvvet }\end{array}$} & $\begin{array}{c}\text { Boru } \\
\text { Bölgeleri }\end{array}$ & \multicolumn{3}{c}{$\begin{array}{c}\text { Doğrudan Tasarım } \\
\text { (SIDD) }\end{array}$} & \multicolumn{2}{c}{$\begin{array}{c}\text { Sayısal Analiz } \\
\text { (PLAXIS 2D) }\end{array}$} & $\begin{array}{c}\text { Değişim } \\
\text { Oranı } \\
\text { (H3) }\end{array}$ \\
\hline & & \multicolumn{4}{c}{ Durum 1: Dolgu Yüksekliklerinin Değişimi } \\
\cline { 2 - 9 } & & H1 & H2 & H3 & H1 & H2 & H3 & \\
\hline \multirow{2}{*}{$\begin{array}{c}M \\
(\mathrm{kNm} / \mathrm{m})\end{array}$} & Taban $\left(0^{\circ}\right)$ & 13 & 25 & 49 & 17.1 & 28 & 46.9 & $\% 4.5$ \\
\cline { 2 - 9 } & Yan Duvar $\left(90^{\circ}\right)$ & -11 & -21 & -42 & -13.2 & -22.9 & -40.6 & $\% 3.5$ \\
\hline & Taç $\left(180^{\circ}\right)$ & 11 & 23 & 44 & 12 & 21.1 & 38.4 & $\% 14.5$ \\
\hline $\begin{array}{c}N \\
N\end{array}$ & Taban $\left(0^{\circ}\right)$ & 26 & 51 & 100 & 33 & 50.9 & 76.6 & $\% 30.5$ \\
\cline { 2 - 9 }$(\mathrm{kN} / \mathrm{m})$ & Yan Duvar $\left(90^{\circ}\right)$ & 74 & 143 & 281 & 70.3 & 120.3 & 207.9 & $\% 35.1$ \\
\cline { 2 - 9 } & Taç $\left(180^{\circ}\right)$ & 22.7 & 44.1 & 87 & 26.1 & 45.4 & 74.3 & $\% 17.1$ \\
\hline
\end{tabular}


Tablo 8 - Boru bölgelerindeki iç kuvvetlerin farklı analiz yöntemleri ile karş̧laştırılması (devami)

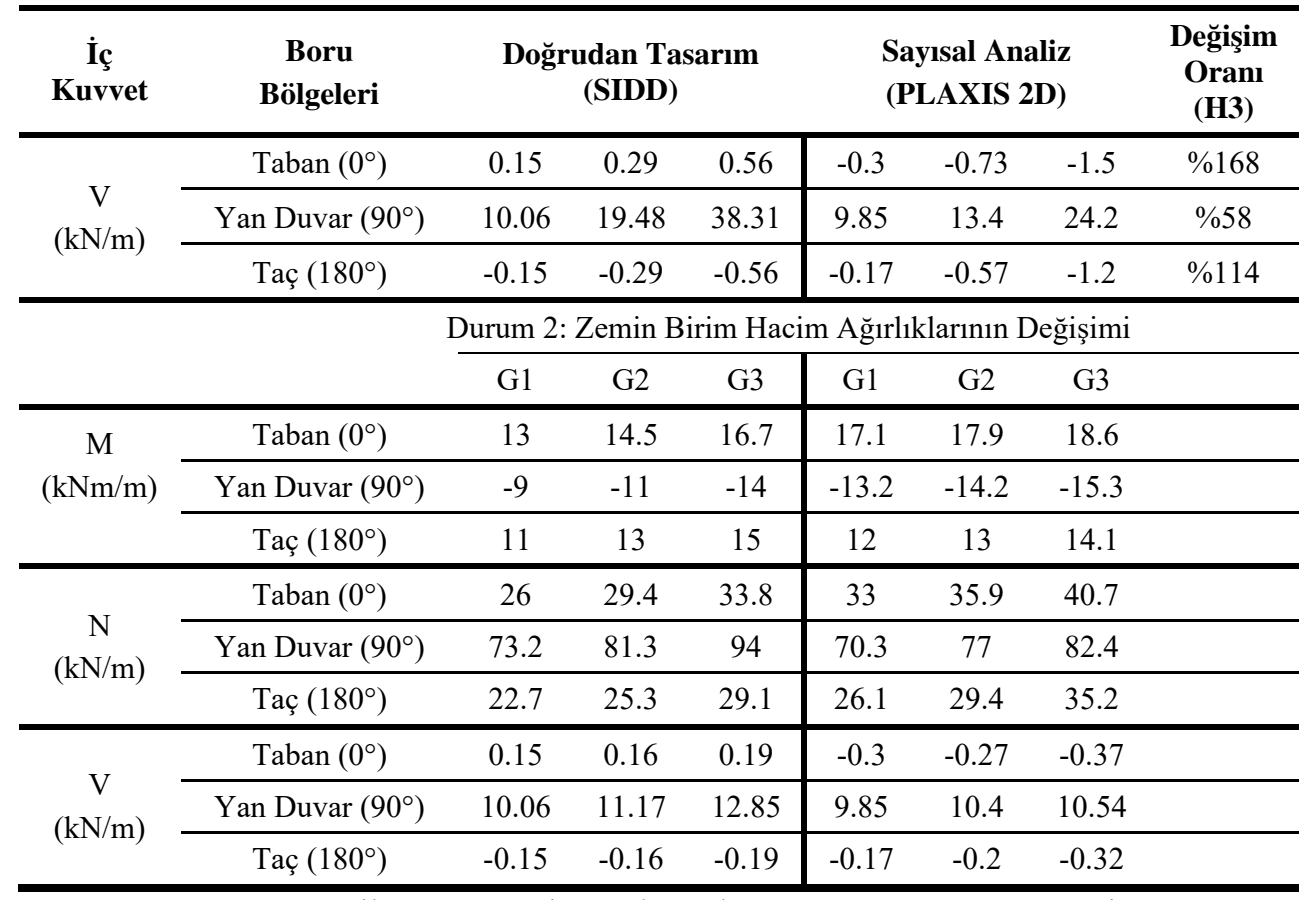

Not: M; Eğilme Momenti, N; Eksenel Kuvvet, V; Kesme Kuvveti

Tablo 9 - Analitik ve sayısal analizlerde boru çaplarına göre elde edilen donatı alanları

\begin{tabular}{|c|c|c|c|c|c|c|}
\hline Boru Dış Çapları (mm) & 800 & 1000 & 1200 & 1400 & 1600 & 1800 \\
\hline Duvar Kalınlıkları (mm) & 120 & 120 & 140 & 140 & 170 & 170 \\
\hline Paspayları (mm) & 90 & 90 & 110 & 110 & 140 & 140 \\
\hline Dolgu Yüksekl $\breve{\mathbf{g}} \square(\mathbf{m})$ & $\mathrm{H} 3$ & $\mathrm{H} 3$ & $\mathrm{H} 3$ & $\mathrm{H} 3$ & $\mathrm{H} 3$ & $\mathrm{H} 3$ \\
\hline \multirow{2}{*}{ Anal $\mathbf{z}$ Yöntem $\square$} & $S I D D$ & SIDD & SIDD & SIDD & SIDD & SIDD \\
\hline & $S A Y^{*}$ & $S A Y^{*}$ & $S A Y^{*}$ & $S A Y^{*}$ & $S A Y^{*}$ & $S A Y^{*}$ \\
\hline \multirow{2}{*}{$\begin{array}{c}\text { As, } \\
\text { Donatı Alanları }\left(\mathrm{mm}^{2} / \mathrm{m}\right)\end{array}$} & 154.2 & 264 & 313.9 & 450.8 & 452.9 & 596.2 \\
\hline & $36.3 *$ & $113.1 *$ & $156.1^{*}$ & $268.5^{*}$ & $290.2 *$ & $419.3^{*}$ \\
\hline Donatı Alanı Değ ş $\mathbf{m} \llbracket(\%)$ & $\% 324$ & $\% 133$ & $\% 101$ & $\% 68$ & $\% 56$ & $\% 42$ \\
\hline
\end{tabular}

Not: SIDD Doğrudan Tasarım Yöntemi, $S A Y^{*}$ Plaxis 2D ile yapılan sayısal analizler. 


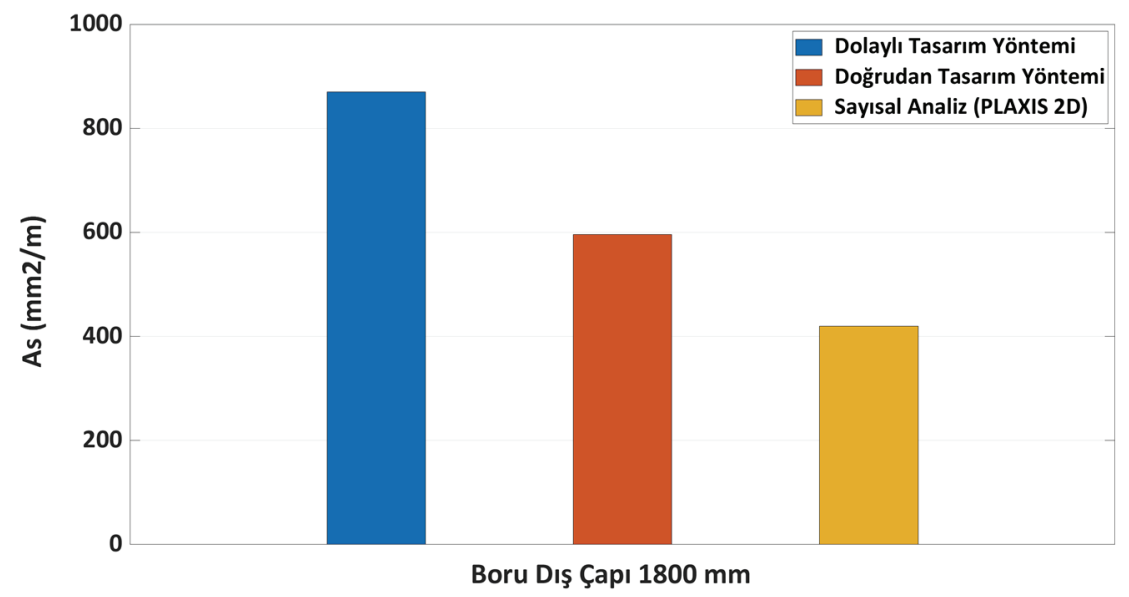

Şekil 15 - Analitik analizlerden ve sayısal analizlerden belirlenen donatı alanları

\section{SONUÇLAR VE TARTIŞMA}

1-) Yapılan parametrik çalışma sonucunda, dolaylı tasarım yönteminde betonarme borunun gömülme yüksekliğinin artırılmasının, betonarme borudaki 0.01 inç $(0.254 \mathrm{~mm})$ 'lik çatlama kriterine denk gelen D-Yüklerini artırdığ 1 tespit edilmiştir. Dolgu yüksekliği arttıkça daha yüksek bir boru sınıfı ve donatı alanı gerekmektedir. Borunun gömüldüğü zemin malzemesinin birim hacim ağırlığı arttığında da D-Yükleri artmıştır. Bu artışın oranı, dolgu yüksekliği arttıkça daha da belirgin hale gelmiştir. Betonarme boru iç çapı arttığında, boru dış çapı da artacağı için kullanılan yataklama katsayısı azalmakta ve böylece borudaki çatlama D-Yükleri de azalmıştır. Özellikle 1m'den daha küçük iç çaplı borular $12 \mathrm{~m}$ gibi yüksek dolgu yüklerine maruz kaldığında, çatlama kriterine denk gelen tasarım D-Yükleri ASTM C76 Şartnamesinde belirtilen doruk D-Yüklerini $(175 \mathrm{kN} / \mathrm{m} / \mathrm{m})$ aşmıştır. Bu nedenle $12 \mathrm{~m}$ gibi yüksek dolgu yüklerine maruz kalacak uygulamalarda, iç çapı 1m'den küçük borular için dolaylı tasarım yönteminin kullanımı önerilmemektedir.

2-) Dolaylı tasarım yönteminde yataklama katsayıları kademeli olarak artırıldığında DYüklerinde tatmin edici bir oranda azalış meydana geldiği görülmektedir. Betonarme borunun kurulduğu hendek genişlikleri kademeli olarak artırıldığında ise Tip 1 (T1) kurulumda D-Yüklerinin artışı nispeten düşük bir orandayken Tip 4 (T4) kurulumda ise DYükleri yüksek bir oranda artış göstermiştir. Standart kurulum tipleri Tip 1'den Tip 4 kuruluma doğru D-Yükleri de doğru orantılı olarak artmıştır.

3-) Doğrudan tasarım yöntemi sonuçlarına göre, betonarme borunun gömülme yükseklikleri arttıkça borudaki iç kuvvetlerin arttığı hesaplanmıştır. En yüksek eğilme momenti değerinin borunun taban bölgesinde oluştuğu tespit edilmiştir. Dolgu yüksekliklerindeki artış, gerekli eğilme donatısı alanlarını da arttırmıştır. Dolgu zeminin birim hacim ağırlıklarındaki artışla birlikte iç kuvvetler de artış göstermiş olup gerekli donatı alanları da artmıştır. Boru dış çapları arttıkça elde edilen iç kuvvetler ve gerekli donatı alanları çok fazla artış göstermiştir.

4-) Doğrudan tasarım yönteminde, SIDD Tip 1'den Tip 4 kuruluma doğru eğilme momentlerinde artış ve eksenel kuvvetlerde azalma belirlenmiştir. Bu azalmanın oranı Tip 1 
(SIDD T1) - Tip 2 (SIDD T2) ve Tip 3 (SIDD T3) - Tip 4 (SIDD T4) arasında oldukça fazla iken Tip 2 (SIDD T2) ve Tip 3 (SIDD T3) arasında nispeten daha azdır. Bunun nedeni ise her iki kurulumda da düşey kemerlenme faktörünün (VAF=1.40) aynı olmasıdır. Bu durum özellikle sayısal analizler ile kıyaslandığında doğrudan tasarım yönteminin sonuçlarının konservatif kalmasında önemli bir etkendir. SIDD Kurulum Tipi 1'den Tip 4 kuruluma doğru gerekli donatı alanı ihtiyacının arttığı belirlenmiştir. Bu durum, SIDD Tip 1 kurulumun en kaliteli kurulum tipi olduğunu göz önünde bulundurulduğunda beklenen bir sonuçtur. Özellikle SIDD Tip 4 kurulum için çok yüksek donatı alanı gereksinimi mevcuttur.

5-) Plaxis 2D 2019 sonlu elemanlar yazılımı ile yapılan sayısal analizlerde Şekil 14'te görüldüğü gibi dolgu yükseklikleri artırıldığında boru bölgelerindeki iç kuvvetlerin ve gerekli donatı alanlarının arttığı belirlenmiştir. Geri dolgu zemininin özellikleri değiştirildiğinde boru bölgelerindeki iç kuvvetlerin ve donatı alanlarının nispeten daha düşük oranda arttığı tespit edilmiştir. Sayısal analizlerde dolgu yüksekliklerinin değişiminin donatı alanlarına etkisinin zemin grubu değişimine göre daha baskın olduğu görülmektedir. Sayısal analizlerde boru dış çapları artırıldığında gerekli donatı alanları da artmıştır.

6-) Sayısal analizlerde boru bölgelerindeki iç kuvvetlerin dolgu yüksekliklerine ve zemin gruplarına bağlı olarak değişiminin etkilerinin SIDD (Doğrudan tasarım) yöntemine göre yüzdesel olarak daha düşük olduğu belirlenmiştir.

7-) Konvansiyonel tasarım yöntemleri olarak bilinen dolaylı ve doğrudan tasarım yöntemlerinde yerel zemin etkisi ve yatak malzemesinin rijitliği analizlerde dikkate alınmamakta, yalnızca boruyu çevreleyen geri dolgu malzemesinin rijitliği dikkate alınabilmektedir. Elde edilen sonuçlar sayısal analizlere göre oldukça muhafazakar tarafta kalmaktadır. Şekil 15'teki grafik incelendiğinde donatı alanları kıyaslandığında dolaylı tasarım yönteminin sayısal yönteme göre \%107 oranında, doğrudan tasarım yönteminin ise $\% 42$ oranında daha fazla donatı alanı gerektirdiği tespit edilmiştir. Gömülü betonarme boru tasarımı yapılırken arazideki yükleme koşularına uygun olacak şekilde zemin-rijit boru etkileşiminin ve geri dolgu malzemesinin rijitliğinin dikkate alınabildiği sayısal analizlerin de yapılması önerilmektedir.

\section{Semboller}

$\begin{array}{ll}\text { RCP } & : \text { Dairesel kesitli betonarme boru } \\ \text { TEB } & : \text { Üç-kenarlı deney } \\ \mathrm{B}_{\mathrm{f}} & : \text { Yataklama katsayısı } \\ \mathrm{F} . \mathrm{S} & : \text { Güvenlik katsayısı } \\ \mathrm{W} & : \text { Toplam yük } \\ \mathrm{D}_{\mathrm{i}} & : \text { Boru iç çapı } \\ \mathrm{D}_{\mathrm{o}} & : \text { Boru dış çapı } \\ \text { VAF } & : \text { Düşey kemerlenme faktörü } \\ \text { HAF } & : \text { Yatay kemerlenme faktörü }\end{array}$




\begin{tabular}{|c|c|}
\hline $\mathrm{d}$ & : Paspayı \\
\hline PL & : Prizma yükü \\
\hline $\mathrm{H}$ & : Dolgu yüksekliği \\
\hline $\mathrm{w}$ & : Zemin birim hacim ağırlığ \\
\hline As & : Birim uzunluk için gerekli eğilme donatısı alanı \\
\hline g & $: 0.85 \mathrm{bf}_{\mathrm{c}}$ \\
\hline $\mathrm{b}$ & : Birim genişlik \\
\hline $\mathrm{h}$ & : Duvar kalınlığı \\
\hline $\mathrm{h} 1, \mathrm{~h} 2$ & : Heger toprak basıncı katsayıları \\
\hline$f_{c}$ & : Beton malzeme dayanımı \\
\hline $\mathrm{f}_{\mathrm{y}}$ & : Donatı malzeme dayanımı \\
\hline$\Phi$ & : Direnç faktörü \\
\hline $\mathrm{M}_{\mathrm{u}}$ & : Birim genişliğe etkiyen tasarım momenti \\
\hline $\mathrm{N}_{\mathrm{u}}$ & : Birim genişliğe etkiyen tasarım eksenel kuvveti \\
\hline HS & : Pekleşen zemin modeli \\
\hline $\mathrm{MC}$ & : Mohr Coulomb zemin modeli \\
\hline $\mathrm{E}_{\mathrm{c}}$ & : Elastisite modülü \\
\hline$\gamma_{\mathrm{c}}$ & : Beton malzeme yoğunluğu \\
\hline $\mathrm{E}_{50}{ }^{\mathrm{ref}}$ & : Referans elastisite modülü \\
\hline $\mathrm{E}_{\mathrm{oed}} \mathrm{ref}^{\mathrm{r}}$ & : Referans ödometre modülü \\
\hline $\mathrm{E}_{\mathrm{ur}}^{\mathrm{ref}}$ & : Referans yükleme boşaltma modülü \\
\hline $\mathrm{m}$ & : Üstel malzeme sabiti \\
\hline$c^{\prime r e f}$ & : Kohezyon \\
\hline $\mathrm{C}_{\mathrm{mi}}$ & : Moment hesabı için boru analiz katsayısı \\
\hline $\mathrm{C}_{\mathrm{ni}}$ & : Eksenel kuvvet hesabı için boru analiz katsayısı \\
\hline $\mathrm{C}_{\mathrm{vi}}$ & : Kesme kuvveti hesabı için boru analiz katsayısı \\
\hline $\mathrm{W}_{\mathrm{i}}$ & : Boru üzerine gelecek yüklerin toplamı \\
\hline $\mathrm{D}_{\mathrm{m}}$ & : Boru ortalama çapı \\
\hline$\phi_{\mathrm{u}}$ & : İçsel sürtünme açısı \\
\hline$v_{\mathrm{ur}}$ & : Poisson oranı \\
\hline$p^{\text {ref }}$ & : Referans gerilme \\
\hline
\end{tabular}




$\begin{array}{ll}\mathrm{R}_{\mathrm{f}} & : \text { Göçme oranı } \\ \mathrm{Bf}_{\mathrm{o}} & : \text { Minimum yataklama katsayıları } \\ \mathrm{Bf}_{\mathrm{e}} & : \text { Yataklama katsayıları } \\ \mathrm{Bf}_{\mathrm{v}} & : \text { Ana yatak katsayıları } \\ \mathrm{G} & : \text { Zemin grupları } \\ \mathrm{M} & : \text { Eğilme Momenti } \\ \mathrm{N} & : \text { Eksenel Kuvvet } \\ \mathrm{V} & : \text { Kesme Kuvveti } \\ \mathrm{T} & : \text { Standart kurulum tipleri } \\ \mathrm{B}_{\mathrm{dt}} & : \text { Hendek genişliği }\end{array}$

\section{Kaynaklar}

[1] Moser A.P, Folkman S, 'Buried Pipe Design', McGraw - Hill, 2008.

[2] Watkins R.K, ' Structural Mechanics of Buried Pipes', 2000.

[3] Mada, H., "Numerical Modelling of Buried Pipes with Flowable Fill as a Backfill Material”, MSc. Thesis, College of Engineering and Mineral Sources at West Virginia University, 2005.

[4] Marston, A.' The Theory of External Loads on Closed Conduits in the Light of the Latest Experiments", Paper presented at the Proceedings of the Highway Research Board 30, Washington, D.C, 1930.

[5] Spangler, M.G, 'The Supporting Strength of Rigid Pipe Culverts', Bulletin 112, Iowa State College, 1933.

[6] Erdogmus, E., Skourup, N.B, Tadros, M, ' Recommendations for Design of Reinforced Concrete Pipe,', Journal of Pipeline Systems Engineering and Practice, ASCE, 1,1, 25 $32,2010$.

[7] ASTM C76-11, 'Standard Specification for Reinforced Concrete Culvert, Storm Drain, and Sewer Pipe', ASTM International, 100 Barr Harbor Drive, PO BoxC700, West Conshohocken, PA, 19428-2959 USA, 2011.

[8] Heger, F.J, 'New Installation Design for Buried Concrete Pipe, Pipeline Infrastructure,', Proceedings of the Conference Sponsored by the Pipeline Division of the American Society of Civil Engineers, 1988.

[9] Heger, F.J., Liepins A.A., Selig, E.T, 'SPIDA: An Analysis and Design System for Buried Concrete Pipe. Advances in Underground Pipeline Engineering', Proceedings of the International Conference Sponsored by the Pipeline Division of the American Society of Civil Engineers, 1985. 
[10] ASCE 15-98, ' Standard practice for direct design of buried precast concrete pipe using standard installation (SIDD)', 1993.

[11] Kurdziel, J. M., McGrath, T.J., 'SPIDA method for reinforced concrete pipe design', J.Transport.Eng, 1991.

[12] Zhao, J. Q., Daigle, L., 'SIDD pipe bedding and Ontario Provincial Standards. Institute for Research in Construction', National Research Council Canada, Ottawa, Canada, 2001.

[13] Erdogmus, E., Tadros, M.,' Behavior and Design of Buried Concrete Pipes", Nebraska Department of Roads Research Reports, Paper 54, 2006.

[14] Erdogmus, E., Tadros, M.,' Behavior and Design of Buried Concrete Pipes Phase II ', Nebraska Department of Roads Research Reports, 75, 2009.

[15] Allard, E., Naggar, E., 'Pressure Distribution around Rigid Culverts Considering SoilStructure Interaction Effects '’, Int. J. Geomech., ASCE, 2016.

[16] Beakley, J., DelloRusso, S., 'Indirect and Direct Design Methods for Design of Reinforced Concrete Pipe', Journal of the Transportation Research Board, Vol.2674 (9), 575-585, 2020.

[17] ACPA, 'Concrete Pipe Design Manual "', American Concrete Pipe Association, 2011.

[18] Kılıç, H., Demirci, O., 'Tip 4 Kurulum ile Betonarme Boru Tasarımı', Teknik Dergi, 33(3), DOI:10.18400/tekderg.832738., 2022. 
